\title{
Cytokine control in human endometrium
}

\author{
Rodney W. Kelly, Anne E. King and Hilary O. D. Critchley \\ MRC Human Reproductive Sciences Unit Centre for Reproductive Biology, \\ 37 Chalmers Street, Edinburgh EH3 9ET
}

\begin{abstract}
Cytokines within endometrium participate in both menstruation and implantation but also contribute to the defence mechanisms of the mucosal epithelium. Endometrium is under the control of steroid hormones, particularly progesterone and, thus, control of cytokines by this steroid is important. Although appreciable numbers of progesterone receptors are not found in endometrial leucocytes, progesterone can modulate cytokines by acting on uterine cells expressing the receptor. The NFKB pathway is important in the control of cytokine synthesis and can modulate production of chemokines, matrix metalloproteinases and the inducible prostaglandin synthesis enzyme COX-2. NFkB activity can be inhibited by progesterone by either stimulating synthesis of $I \kappa B$, the molecule that restrains NFKB in the cytosol, or after binding to the nuclear receptor, competing with $\mathrm{NFKB}$ for recognition sites on the relevant gene. In this way, progesterone can limit pro-inflammatory pathways. The major palliatives for endometrial dysfunctions such as menorrhagia and dysmenorrhoea have been the non-steroidal anti-inflammatory drugs that inhibit prostaglandin synthesis. Prostaglandins have major effects on cytokine production but the direct action of prostaglandin E on leucocytes is not a pro-inflammatory response but is to stimulate interleukin 10 and inhibit interleukin 12 synthesis. The likely effect of the non-steroidal anti-inflammatory drugs is on the cells surrounding the small blood vessels, where a synergistic action between prostaglandin and chemokine will induce leucocyte entry and activation leading to lysis of connective tissue and menstruation. At the time of implantation, tight control of cytokine synthesis is required. Although leukaemia inhibitory factor is essential to implantation, the mouse knockout models show that the prostaglandin system is also essential but that there are mutually supportive pathways that compensate for the knockout of many cytokines.
\end{abstract}

Critical reproductive events in endometrium such as menstruation and implantation have an inflammatory character (Finn, 1986). Menstruation and implantation involve both prostaglandins and cytokines and are accompanied by the ingress of leucocytes into the endometrium. Moreover, oedema is characteristic of endometrium both premenstrually and at the time of implantation. Endometrial physiology relating to these events is still poorly understood and this ignorance hinders better medical approaches to major pathologies of menstruation, such as menorrhagia and dysmenorrhoea, and failure of implantation.

One of the most revealing studies on the mechanism of menstruation was published 60 years ago by Markee (1940) who transplanted endometrium to the anterior chamber of the monkey eye, where events surrounding menstruation could be observed microscopically. The early events of menstruation involve vasoconstriction of the spiral blood vessels followed by a relaxation of the arterioles

Email: r.kelly@hrsu.mrc.ac.uk and reperfusion of the tissue. Prolonged periods of vasoconstriction that would have induced hypoxia and the inevitable reperfusion injury were also observed. Such periods of vasoconstriction have not been confirmed in women in studies with techniques such as Doppler flow (Gannon et al., 1997) and xenon clearance (Fraser et al., 1987), but such techniques are unlikely to detect highly localized changes. Hypoxia would certainly be a sufficient cause of cytokine release since hypoxia affects the NFkB pathway (Royds et al., 1998) and many genes have hypoxic response elements. Re-exposure to oxygen is likely to be accompanied by an upregulation of cytokine (Karakurum et al., 1994) matrix metalloproteinase (MMP) (Fujimura et al., 1999; Heo et al., 1999) vascular endothelial growth factor (VEGF) (Goldberg and Schneider, 1994; Sharkey et al., 2000) and prostaglandin (Kishimoto et al., 1997) production. However, the events preceding vasoconstriction are less clear. The early events in menstruation are initiated by the withdrawal of the circulating progesterone as a result of the demise of the corpus luteum and are likely to involve cells close to the spiral arterioles where the constriction 


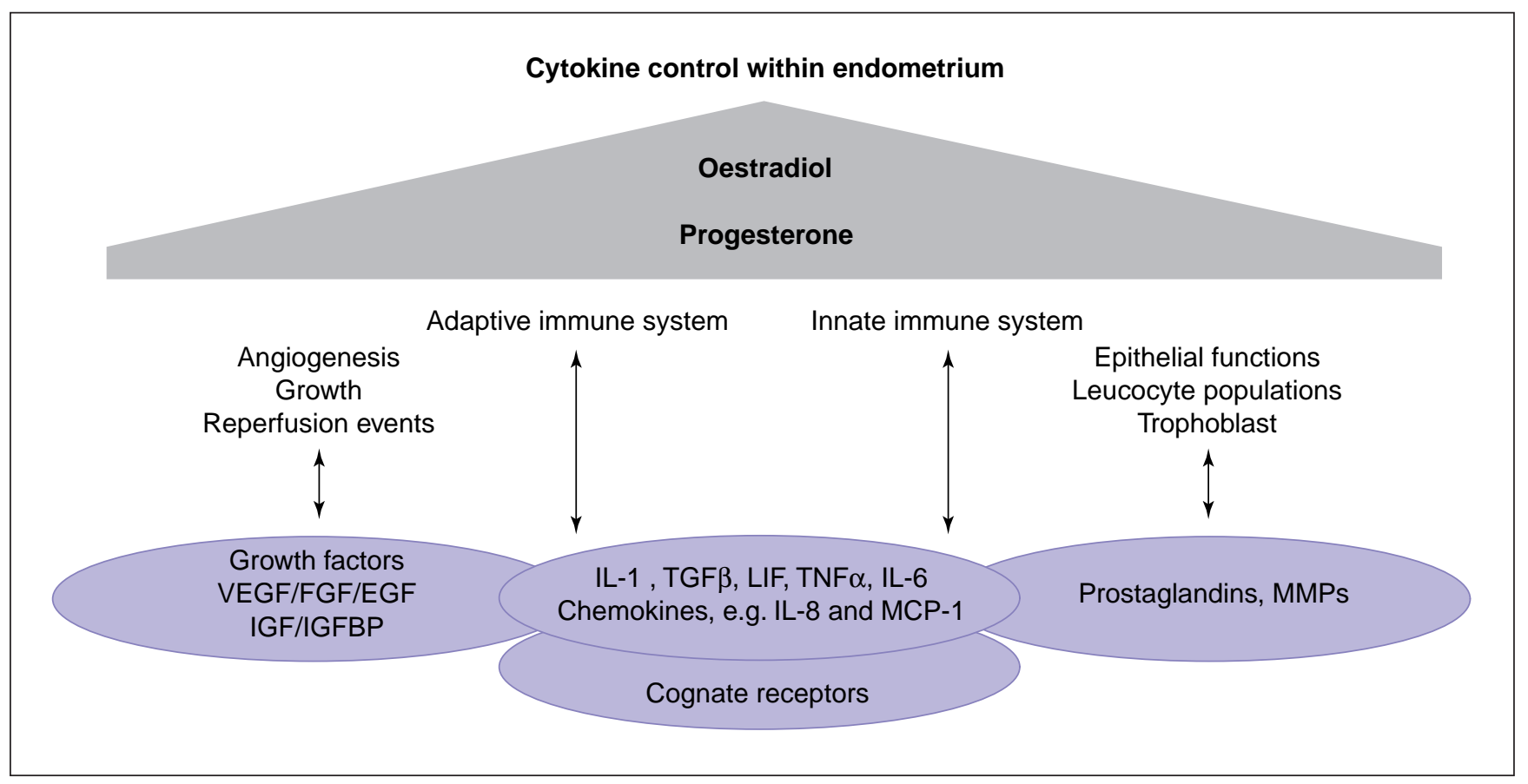

Fig. 1. Summary of factors affecting endometrial cytokine release. Overall control (direct or indirect) of cytokine release is exercised by the steroid hormones. The mucosal surface of endometrium can participate in both innate and adaptive immune responses and is involved in protein and fluid secretion into the lumen. In addition, growth of new tissue and accommodation of the trophoblast all involve cytokine release and control. EGF, epidermal grown factor; FGF, fibroblast growth factor; IGF, insulin-like growth factor; IGFBP, IGF-binding protein; IL, interleukin; LIF, leukaemia inhibitory factor; MCP, monocyte chemotactic protein; MMP, matrix metalloproteinase; TGF, transforming growth factor; TNF; tumour necrosis factor; VEGF, vascular endothelial growth factor.

occurs. Consequently, there are two phases: one that is initiated by decreasing progesterone and might in early stages be reversible, and a second that is inevitable after hypoxia and reperfusion. This second phase is effectively progesterone independent and involves leucocytes and epithelial cells as well as stromal cells. Most of the cells participating in this second phase will have no progesterone receptors at this point in the ovarian cycle since epithelial cells will have lost their receptors and uterine leucocytes do not possess nuclear progesterone receptors (King et al., 1996).

This review examines the control of cytokines in endometrium during menstruation and in the event of conception. Both these processes involve exposure to progesterone, which is transient in the normal cycle but prolonged after implantation. Cytokines within human endometrium are controlled either directly by steroids or indirectly through cyclical changes in factors such as growth, secretion, immune defence and, after fertilization, the implanting embryo (Fig. 1). In recognition of the complexities involved, emphasis will be placed on cytokine-steroid, cytokineprostaglandin and cytokine-cytokine interactions. Several areas such as angiogenesis and its control are reviewed elsewhere (Smith, 1998) and will not be addressed further here.

\section{Morphological components of human endometrium}

The main functions of human endometrium are the provision of a hormone-defined implantation window (Tabibzadeh et al., 1998), the ability to instigate its own demise in the absence of pregnancy, and the function shared with all other mucosal surfaces of protection against invading pathogens. These different functions involve interactions between diverse constituent cell types and are both influenced by ovarian steroid hormones and controlled in a paracrine fashion within microenvironments (Tabibzadeh, 1995). Human endometrium has a mucosal epithelial surface consisting of surface and glandular epithelium, a heterologous stroma and a characteristic vascular system found only in menstruating species (oldworld primates and certain bats (Rasweiler, 1991)). These components interact in the control of cytokine synthesis and release under ultimate hormonal control.

\section{Stroma}

The stroma of human endometrium consists of fibroblasts, some macrophages and T cells but few B cells (Loke and King, 1995). A population of large granular lymphocytes (LGL) appears in the late secretory phase and numbers increase further in early pregnancy. These cells are natural killer (NK) cells, which display abundant surface expression of a specific adhesion molecule CD56 but are $\mathrm{CD}^{-}$- and $\mathrm{CD}^{-} 6^{-}$-negative. The function of these NK cells is not certain but it is known that they interact with the class 1 human leucocyte antigens (HLA) expressed on 
extravillous trophoblast and may limit trophoblast invasion (Loke and King, 1996). In later decidua, the number of LGLs declines and these cells are sparse at term (Loke and King, 1995). Endometrial LGLs produce interferon- $\boldsymbol{\gamma}(\mathrm{IFN}-\boldsymbol{\gamma})$, particularly when interacting with macrophages or stimulated with interleukin 12 (IL-12) and IL-2 (Marzusch et al., 1997). In addition. IFN- $\gamma$ is secreted by uterine neutrophil-like cells in the stroma (Yeaman et al., 1998) or from lymphoid aggregates in the basalis (the lower one- third of endometrium, which is not shed at menstruation) (Tabibzadeh, 1994). The uterine lymphoid aggregates appear to be structured with $T$ $\left(\mathrm{CD}^{+}\right)$and B cells surrounded by a 'halo' of monocytes and macrophages (Yeaman et al., 1997). These structures, which are predominant at mid-cycle and in the secretory phase, may play an important role in implantation and, as a source of IFN- $\gamma$, may stimulate endometrial stromal cell production of monocyte chemotactic protein (MCP-1), IL-6 and granulocyte colony-stimulating factor and reduce production of IL-8 (Nasu et al., 1998).

At about day 23 of the menstrual cycle, when progesterone concentrations are still high, endometrial stromal cells begin to undergo a transformation to a phenotype characteristic of cells in early decidua. The process commences in cells surrounding the spiral arterioles and gradually spreads through the endometrium (Buckley and Fox, 1989) becoming particularly evident if pregnancy ensues. The decidual cell is rounded, has myofibroblast characteristics (Oliver et al., 1999) and secretes prolactin. Although progesterone is likely to be the initiating agent in vivo, a combination of progesterone and agents that raise intracellular CAMP is necessary for effective decidualization in vitro (Frank et al., 1994; Tang et al., 1994; Telgmann and Gellersen, 1998; Brosens et al., 1999). Agents such as relaxin (Chen et al., 1988) PGE (Frank et al., 1994) and FSH (Tang et al., 1994) all increase cAMP concentrations in endometrial stromal cells in conjunction with progestins. In human endometrial stromal cells, continuous stimulation of protein kinase A by CAMP is necessary to maintain prolactin production and this is achieved by a reduction in the availability of the negative regulatory subunit $\mathrm{R} 1 \alpha$ (Telgmann and Gellersen, 1998). The absolute necessity of progesterone has been questioned since women with very low peripheral blood progesterone concentrations can have normal pregnancies (Tang et al., 1994) and decidualization can occur in vitro with increased cAMP alone (Telgmann and Gellersen, 1998). In addition, in rodents, progesterone alone is sufficient to induce decidualization (Paria et al., 1999). These findings indicate that, in women, some other, unidentified agent influenced by progesterone and CAMP may be elaborated in secretory phase endometrium that is directly responsible for decidualization and prolactin production. Decidualization can be prevented by IL-1 (Kariya et al., 1991; Frank et al., 1995; Mizuno et al., 1999), which reduces prolactin production as well as preventing differentiation to the decidual phenotype. However, it is not known whether IL-1 interacts with the adenylate cyclase system in endometrial cells.

\section{Epithelium}

The epithelial surfaces of the endometrium have a dual function in both providing for implantation and for defence against infection. The role of the endometrial epithelium in implantation has been reviewed elsewhere (Aplin, 1997) and will not be addressed further here. Defence mechanisms include transepithelial passage of antibodies in the form of IgA (Kelly and Fox, 1979) as part of the adaptive immune response, but depend to a large extent on innate defences. Luminal secretions contain peptides of low molecular weight with antibacterial activity, defensins (Quayle et al., 1998; Valore et al., 1998) and lysosyme (Tauber et al., 1993), as well as compounds such as secretory leucocyte protease inhibitor (SLPI), which have anti-viral, anti-fungal and anti-bacterial activity (Hiemstra et al., 1996; Tomee et al., 1997; Wiedow et al., 1998). SLPI is expressed in human endometrial epithelial cells (King et al., 2000) and may contribute to the luminal defences of the uterus. Other components of the innate immune defences with anti-microbial activity, such as the $\theta$ defensins, are still being revealed (Tang et al., 1999) and it now appears that defensins can also link to the adaptive immune system by attracting both dendritic and memory T cells (Yang et al., 1999).

Endometrial epithelial cells are the major sources of several vasoactive substances such as prostaglandins (Lumsden et al., 1984) and endothelins (Salamonsen et al., 1999) that have been implicated in menstruation. However, these compounds are found in other mucosal epithelial tissues such as the gut (Egidy et al., 2000) and may have a prime function as modulators of epithelial function, as well as contributing to constriction of the endometrial spiral arterioles.

\section{Vasculature}

Cells surrounding the spiral arterioles are reported to be the origin of the decidualized stromal cells and have been shown to have myo-fibroblast characteristics. These stromal cells replicate during the secretory phase of the cycle (Abberton et al., 1999), retain their progesterone receptors throughout the cycle (Critchley and Healy, 1998) and are likely to have a critical role in vascular control.

Significant health care resources are used to treat excessive blood loss at menstruation (menorrhagia) (Stirrat, 1999). It is important to consider the role cytokine control associated with endometrial blood vessels may play in this complaint. The blood supply to the superficial two-thirds of the endometrium is provided by spiral arterioles, structures found only in menstruating species. These vessels grow with increasing coiling until day 3 after ovulation (Ferenczy et al., 1979). The factors governing new blood vessel growth have been reviewed elsewhere (Smith, 1998) and will not be addressed further here. The rate of proliferation of smooth muscle cells associated with the blood vessels increases after ovulation, and a deficiency in proliferation has been associated with menorrhagia (Abberton et al., 1999). Studies on keratinocyte growth factor (KGF) show that this factor is progesterone dependent and contributes 
to myofibroblast cell growth (Koji et al., 1994). Withdrawal of steroid during the late second half of the secretory phase leads to shrinkage of the functionalis and compression of the vessels (Markee, 1940). Several vasoactive agents may be released at this time and, although compounds such as endothelins, which are predominantly synthesized in glandular tissue, may contribute (Campbell and Cameron, 1998), it is hypothesized that a subset of stromal cells plays a role in the initiation of menstruation. Mechanisms that induce the initial vasoconstriction are triggered by decreasing progesterone concentrations and, in the late secretory phase of the cycle, progesterone receptors are found in stromal perivascular cells but not in the epithelial cells of the functionalis layer (Critchley et al., 1994a), placing the stromal cell in a key position. Once change is established, tissue rearrangement, involving epithelial cells as well as stromal cells, commences in an essentially irreversible process. Thus, menstruation can be considered as two seamlessly connected events.

\section{Two phases of menstruation} Phase 1: initiation of vasoconstriction - cytokine
changes due to steroid withdrawal

Menstruation involves sloughing-off of all but the basal third of the endometrium and there is associated extensive tissue destruction. Lytic enzymes such as MMPs, which degrade the extracellular matrix (ECM), and proteases are clearly involved in this process and are likely to be derived from epithelial stromal and recruited leucocytes (Salamonsen and Woolley, 1999). However, menstruation is probably initiated by progesterone withdrawal and, therefore, initial events are likely to be triggered by cells that express progesterone receptors. By the latter half of the secretory phase, progesterone receptors are absent from the glandular and surface epithelium in the superficialis (Critchley et al., 1994a) and have not as yet been identified in leucocytes. It is significant that progesterone receptors are expressed in stromal cells including those surrounding the blood vessels (Perrot-Aplanat et al., 1994; Critchley and Healy, 1998). Although there are important paracrine interactions between stromal and epithelial cells (Tabibzadeh, 1995), a more likely location for early responses to a decrease in progesterone is the grouping of myofibroblast cells surrounding the spiral arterioles. The ECM associated with these perivascular cells will have been stabilized in the presence of progesterone and oestradiol (Lockwood et al., 1998) and is therefore vulnerable to progesterone withdrawal. These perivascular cells are distinguished by a marked expression of both prostaglandins and cytokines (Cheng et al., 1993a,b; Critchley et al., 1994b, 1999; Jones et al., 1997). If prostaglandins are modulating vascular permeability through actions on the perivascular cells, control of prostaglandins by the catabolic enzyme prostaglandin-15-dehydrogenase becomes critical. The activity of this enzyme decreases in the perivascular cells of decidua after progesterone antagonism
(Cheng et al., 1993b) and prostaglandin dehydrogenase $(\mathrm{PGDH})$ is likely to be maintained in decidual stromal cells by a combination of progesterone and increased intracellular cAMP (Greenland et al., 2000). Since the perivascular cells are thought to proliferate in early pregnancy to form the population of myofibroblast-like, decidualized stromal cells, they are pivotal in their response to progesterone, initiating menstruation in response to decreasing steroid concentrations or, conversely, supporting pregnancy in response to increasing steroid concentrations (Fig. 2).

Perivascular cells in human endometrium may have a distinct mechanism for initiating prostaglandin and cytokine synthesis since they display an abundant CD40 signal on their surface (King et al., in press). CD40 is a member of the tumour necrosis factor (TNF) receptor superfamily, and its ligand is a TNF- $\alpha$-like protein CD40L or CD154. Although first recognized on B cells, the CD40-CD40L interaction has been shown to stimulate prostaglandin and IL-8 release from fibroblasts (Sempowski et al., 1998; Zhang et al., 1998). CD40-CD40L interactions may result in the activation of the NFKB pathway (Rothe et al., 1995; Liu et al., 1996; Takeuchi et al., 1996) (Fig. 3) or, alternatively, CD40 activation may affect gene transcription through the JAK-STAT (JAK3-STAT-3 and -6) pathway (Hanissian and Geha, 1997). The source of CD40L within endometrium has not yet been identified but possible sources include lymphocyte aggregates or lymphocytes that are attracted into the tissue by chemokines. Control of the CD40-CD40L system in endometrium is unknown, but where the NFKB pathway is involved, an influence of progesterone is expected (Kalkhoven et al., 1996). Thus progesterone withdrawal could activate such a system in a receptor-dependent process.

In the secretory phase of the menstrual cycle, the circulating concentrations of progesterone are of the order of 10-30 pmol I-1 whereas, in placenta and decidua, concentrations of $20 \mu \mathrm{mol}{ }^{-1}$ have been reported (Challis and Mitchell, 1988). The high concentrations of progesterone within the pregnant uterus are consistent with non-genomic membrane effects of progesterone and these have been implicated in both its immunosuppressive action on T cells (Ehring et al., 1998) and its action on the oxytocin receptor in rats (Grazzini et al., 1998). Several of these progesterone effects can be related to the blockage of potassium channels, which is not receptor-mediated (Ehring et al., 1998). However, in the non-pregnant uterus, the low progesterone concentrations, the cyclical variation of progesterone receptors and the profound changes brought about by the progesterone receptor antagonist RU486 (Cameron et al., 1996) indicate a classical receptor-mediated mechanism.

There are similarities between glucocorticoids and progesterone in structure, receptor sequence and response elements. Moreover, both glucocorticoids and progestins inhibit cytokine expression and the way in which they affect cytokine synthesis has now been recognized as an NFkBmediated event (McKay and Cidlowski, 1999). 


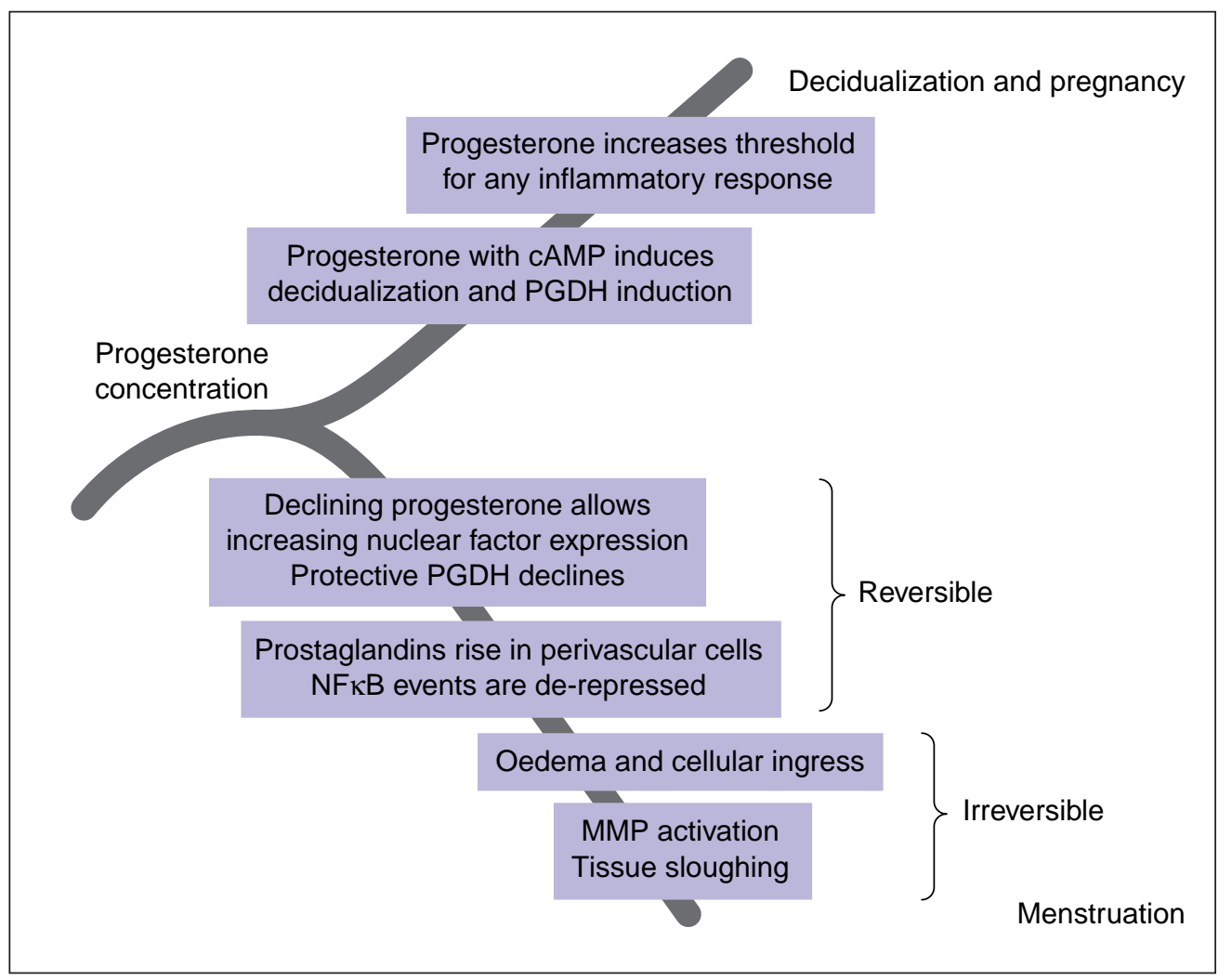

Fig. 2. The concentration of progesterone to which the endometrium is exposed is a major factor in governing cytokine concentrations in endometrium. If progesterone increases due to support from the corpus luteum, decidualization changes occur to support the implanting blastocyst. However, if progesterone decreases, changes are started that culminate in oedema and cellular (monocytes and neutrophils) influx, which participate in endometrial breakdown and sloughing. MMP, matrix metalloproteinase; PGDH, prostaglandin dehydrogenase.

$\mathrm{NF \kappa B}$ is a transcription factor responsible for the upregulation of genes involved in the inflammatory response. It is sequestered in an inactive state in the cytoplasm by the endogenous inhibitor I $\kappa B$. Most activators of NFKB cause the degradation of $\mathrm{I} \mathrm{KB}$ (via a phosphorylation-ubiquitinationproteasome pathway) allowing free NFאB to enter the nucleus (Baldwin, 1996). The molecular mechanisms leading to the degradation of IKB were unclear until recently but it is now apparent that a series of protein kinases are likely to be involved in the signalling. I $\mathrm{KB}$ is phosphorylated by an $I \kappa \mathrm{B}$ kinase (IKK) complex consisting of several proteins, including the kinases IKK $\alpha$ and IKK $\beta$ (DiDonato et al., 1997) and the scaffolding protein IKK $\gamma$. IKK $\alpha$ and IKK $\beta$ may have different functions and it appears to be IKK $\beta$ that is predominantly involved in proinflammatory signalling to NFKB (Delhase et al., 1999; Takeda et al., 1999). Upstream mitogen-activated protein kinase kinase kinases (MAPKKK) are involved in the phosphorylation of the IKK complex. Particularly, NFKB-inducing kinase (NIK; Malinin et al., 1997) and MAPK Erk kinase kinase 1 (MEKK1; Lee et al., 1997) activate the kinase activity of the complex. These agents are activated by distinct stimuli (Nakano et al., 1998) but may also act synergistically (Nemoto et al., 1998). An inducible form of IKK
(IKKi) has been reported in rats (Shimada et al., 1999) and, if there is a similar system in humans, an alternative control mechanism in the NFKB cascade will have been established.

Glucocorticoid function in controlling cytokine synthesis and release is better understood than progesterone function due, in part, to the limited expression of progesterone receptors in endometrial cell lines, which means that much of the experimental data on progesterone action is derived from studies on the breast cancer epithelial line T47D, which constitutively expresses progesterone receptors (Horwitz et al., 1982). Both glucocorticoids and progesterone exert major control via effects on the NFKB pathway. However, not all glucocorticoid suppression of cytokines is NFKB-dependent (Bourke and Moynagh, 1999) and the same may yet be shown for progesterone. Glucocorticoids stimulate the production of $1 \kappa B \alpha$ and, in the T47D cell line, progesterone has a similar action (Wissink et al., 1998) (Fig. 4). A second mechanism by which progesterone might affect NFKB activity is by direct competition between different transcription factors, in this case steroid receptors and NFKB for adjacent binding sites on the gene. This mechanism has been suggested for both the glucocorticoid receptor (Caldenhoven et al., 1995) and 


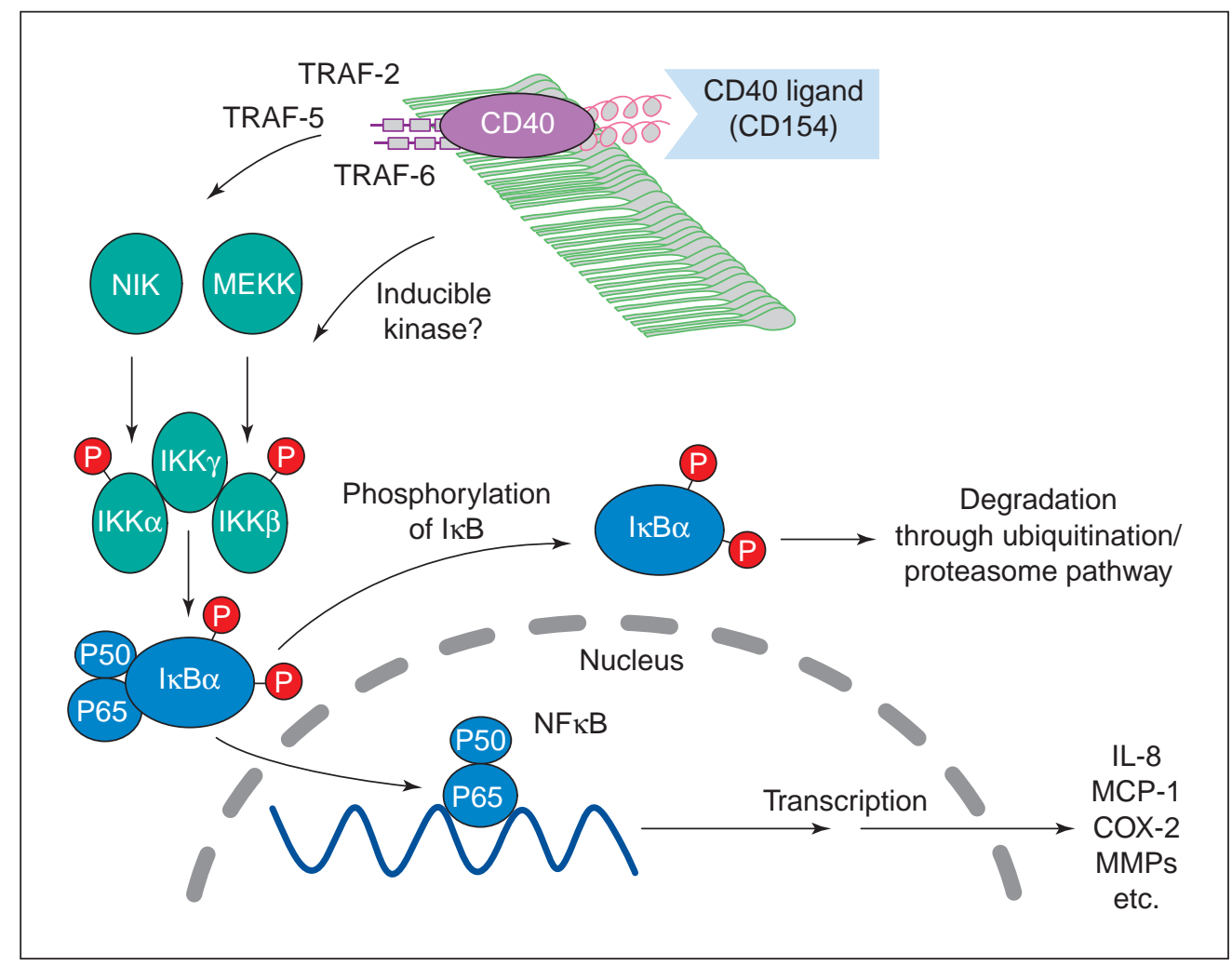

Fig. 3. Cytokine control by $\mathrm{NF \kappa B}$ and $\mathrm{CD} 40 . \mathrm{CD} 40$ is expressed in the cells surrounding the small blood vessels of human endometrium and myometrium although the nature of the ligand is not known. CD40 can alternatively act through the JAK-STAT pathway to affect cytokine transcription. IKK, IKB kinase; MEKK, mitogen-activated protein kinase Erk kinase kinase; NIK, NFKB-inducing kinase; TRAF, tumour necrosis factor receptor-associated factor.

the progesterone receptor (Kalkhoven et al., 1996). A third mechanism could be the competition between NFKB and the steroid receptors for a common essential cofactor (McKay and Cidlowski, 1999).

There is experimental evidence from in vitro systems that progesterone suppresses the release of cytokines such as IL-8 (Ito et al., 1994; Kelly et al., 1994) and MCP-1 (Kelly et al., 1997) that are known to be, at least in part, under the control of NFKB. In T47D cells, the production of MCP-1 is attenuated by progesterone concentrations consistent with those seen in the secretory phase of the menstrual cycle but, in these cells, no effect of glucocorticoid is seen (Kelly et al., 1997).

Studies in vivo have shown that there is reduced chemokine release from endometrium under the influence of progesterone and that progesterone withdrawal or the administration of antiprogestin stimulates chemokine expression and release (Critchley et al., 1996; Jones et al., 1997).

\section{Phase 2: activation of lytic mechanisms}

The consequences of increased cytokine production in a perivascular location may be twofold. First, both PGE and IL-8 are synthesized and, as a result of their synergistic action (Foster et al., 1989; Rampart et al., 1989; Colditz, 1990), neutrophils will be attracted into the tissue. Second, the effects of progesterone withdrawal will induce vasoconstriction-vasodilatation cycles with associated hypoxia and reperfusion which will, in turn, induce NFKB (Royds et al., 1998). NFKB activation will further induce prostaglandin and cytokine release, which will affect lytic enzyme activity (Luca et al., 1997). These effects are likely to be seen in all tissue affected by the intense vasoconstriction, although studies in rhesus monkeys show that such constriction is not uniform throughout the endometrium.

The exact role for infiltrating leucocytes in menstruation has yet to be clarified but they are likely to be a major source of MMPs and proteases (Salamonsen and Woolley, 1999). The neutrophil has specific granules that contain neutrophil collagenase (MMP-8) and is also a potential source of large amounts of protease (elastase). Local control of MMPs will be by cytokines since a major stimulator of MMP-1 is IL- $1 \alpha$ derived from the glandular epithelium (Singer et al., 1997). A withdrawal of progesterone dominance will allow both synthesis of IL-1 and the action of IL-1 to release MMP-1 and thus allow a geared enhancement of MMP-1 (Singer et al., 1997). Although other MMPs such as MMP-9 in endometrium are stimulated by 


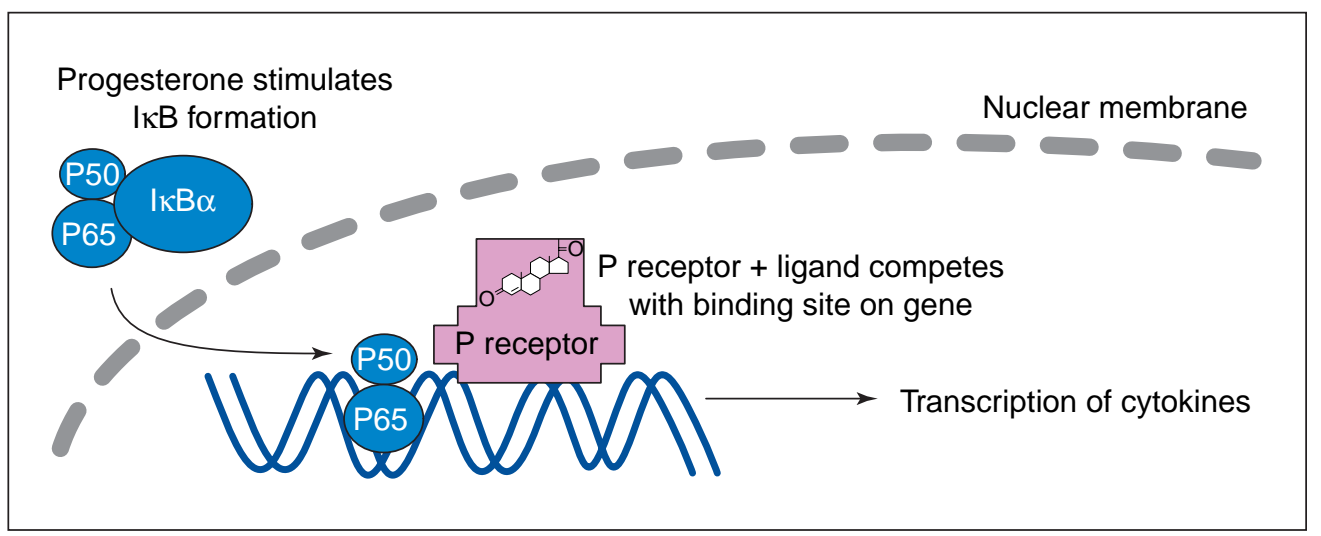

Fig. 4. Two separate mechanisms for progesterone (P) control of the NFkB pathway have been described. Either the progesterone receptor acts as a competing transcription factor displacing NFKB (Kalkhoven et al., 1996) or progesterone can stimulate the synthesis of the inhibitory binding protein I $\mathrm{KB} \alpha$.

cytokines, such stimulation is not sustainable, whereas MMP-1 concentrations remain high for $48 \mathrm{~h}$ (Singer et al., 1999). It appears that TIMPs, the endogenous inhibitors of MMPs, are not increased by cytokines in parallel with the MMPs (Lockwood et al., 1998; Singer et al., 1999) and thus cytokine effects should result in the destruction of the supporting matrix of the endometrium and eventually lead to sloughing of tissue.

Thus, there are two pathways for activation of the lytic enzymes induced by decreasing progesterone concentrations: the induction of leucocyte entry by raising the synthesis and activity of chemotactic and vascular-active agents or a direct action on the local control of MMPs. Which of these mechanisms is triggered initially by the demise of the corpus luteum is a matter of current debate (Salamonsen and Woolley, 1999).

\section{Cytokine changes with implantation}

If corpus luteum activity is maintained by embryo secretions, control of many of the cytokines by progesterone will continue. However, other cytokine interactions that favour survival of the conceptus will occur in local microenvironments and, inevitably, decidual cells will be affected by local production of progesterone by the trophoblast. Other cytokine changes must occur at the time of implantation to allow accommodation of the trophoblast by the maternal immune system. The trophoblast restricts expression of major histocompatability complex (MHC) antigen but there is considerable evidence that other protective mechanisms are in place during pregnancy. There is evidence of T-cell toxicity by trophoblast (Munn et al., 1998) and animal studies have indicated a predominance of Th-2 cytokines (which favour a humoral or antibody immune response) over Th- 1 cytokines such as IFN- $\gamma$ (which favour a cell-mediated immune response)(Wegmann, 1990). Notwithstanding this accommodation, infection can never be allowed to threaten the survival of the mother and thus, although progesterone may raise the threshold of cytokine production, cytokine-mediated inflammatory responses are possible. During early pregnancy, before extensive changes to the vascular architecture are established, blood reaches the placenta via the capillary network (Carter, 1997) and implantation results in an increase in blood flow to the site. Prostaglandins are implicated in this phenomenon (Kennedy, 1980) but other agents such as nitric oxide (NO) may also be involved. NO is important at the time of implantation since antagonism of both $\mathrm{NO}$ and progesterone results in an almost complete absence of implantation sites in rats (Chwalisz et al., 1999). In women, NO synthase is present in glandular epithelium stroma and myometrial blood vessels (Telfer et al., 1995) and, at the time of implantation, expression of the inducible form of the synthase (INOS) is mediated by progesterone (Buhimschi et al., 1996).

The following section covers some of the complex interactions at the time of implantation.

\section{Leukaemia inhibitory factor and gp130-related cytokines}

A group of cytokines that react with receptors associated with gp130 appears to play an important role in implantation. This group comprises leukaemia inhibitory factor (LIF), IL-6, oncostatin $M$, ciliary neurotrophic factor (CNTF), cardiotrophin (CT-1) and IL-11. Whereas many gene ablation experiments have failed to show clear effects because of redundancy of function, the homozygous LIF knockout mice are infertile since they fail to accommodate implantation (Stewart et al., 1992). Similarly, ablation of the LIF receptor leads to implantation failure (Ware et al., 1995). Since LIF is involved in the decidual reaction (Stewart, 1994), necessity for LIF in implantation may be restricted to those species with relatively invasive implantation. In sheep, in which implantation is synepitheliochorial, LIF may be facilitatory but not obligatory (Vogiagis and Salamonsen, 1999). 
Table 1. Studies on gene ablation that reveal essential mediators in implantation

\begin{tabular}{|c|c|c|}
\hline Gene knocked out & Observations & Reference \\
\hline LIF & $\begin{array}{l}\text { LIF -/- animals fail to implant due to a decidual defect. Numbers of stem } \\
\text { cells in spleen and bone marrow may be reduced. }\end{array}$ & Stewart, 1994 \\
\hline COX-2 & $\begin{array}{l}\text { The COX product essential for implantation has not been identified. } \\
\text { Although PGE will be important, } \mathrm{PGI}_{2} \text { may interact through the PPAR } \delta \\
\text { receptor. }\end{array}$ & $\begin{array}{l}\text { Lim et al., 1997; } \\
\text { Lim et al., 1999a }\end{array}$ \\
\hline IL-11 receptor & $\begin{array}{l}\text { The IL-11, LIF and IL- } 6 \text { receptors are all gp130 linked and all appear to play } \\
\text { a role in implantation. }\end{array}$ & $\begin{array}{l}\text { Bilinski et al., 1998; } \\
\text { Robb et al., } 1998\end{array}$ \\
\hline CSF-1 & $\begin{array}{l}\text { Early studies show that this gene is important but effects may be central since } \\
\text { CSF affects migroglial cells involved in } \mathrm{GnRH} \text { release. }\end{array}$ & Cohen et al., 1999 \\
\hline Hoxa 11 & Hoxa 11 is essential for differentiation of uterine stromal and epithelial cells. & Gendron et al., 1997 \\
\hline Hoxa 10 & $\begin{array}{l}\text { The defect is associated with a deficiency of EP3 and EP4 receptors. LIF is not } \\
\text { affected. }\end{array}$ & $\begin{array}{l}\text { Benson et al., 1996; } \\
\text { Lim et al., 1999b }\end{array}$ \\
\hline Cyclin D3 & Implicated in implantation. & Das et al., 1999 \\
\hline SRC-1 & Decreased organ growth but still fertile. & Xu et al., 1998 \\
\hline Prolactin receptor & $\begin{array}{l}\text { There is an implantation defect in mice lacking the prolactin receptor but this } \\
\text { defect may also be a central effect. }\end{array}$ & $\begin{array}{l}\text { Ormandy et al., 1997; } \\
\text { Bole-Feysot, et al., } \\
1998\end{array}$ \\
\hline Progesterone receptor & $\begin{array}{l}\text { Ablation of the progesterone receptor leads to inappropriate inflammation in } \\
\text { the uteri of mice. }\end{array}$ & Lydon et al., 1995 \\
\hline
\end{tabular}

CSF, colony stimulating factor; EP, prostaglandin E receptor; IL, interleukin; LIF, leukaemia inhibitory factor; PG, prostaglandin; PPAR, peroxisome proliferator; SRC, steroid receptor coactivator.

Although targeted disruption of the IL-6 gene leads to fertile mice, those lacking the IL-11 receptor are infertile (Bilinski et al., 1998)(Table 1). Defects associated with decidual development are observed after implantation has occurred. Since LIF, IL-11 and IL-6 are all implicated in acute phase protein expression in the liver, and since some of the proteins such as $\alpha 2$-macroglobulin (Bell, 1979) that are expressed in early decidua are also acute phase proteins, there may be a specific role for the gp130associated receptors in controlling protein synthesis and release. This hypothesis would certainly accord with the lack of optimum decidualization associated with both LIF (Stewart, 1994) and IL-11 (Bilinski et al., 1998) deficiency, with LIF possibly acting at an earlier stage in the implantation process. Such stimulation by LIF is likely to be regulated by IL-1, TNF- $\alpha$ and transforming growth factor $\beta$ (TGF $\beta$ ) within the decidua (Sawai et al., 1995) and is consistent with early reports that favoured an effect of LIF on the blastocyst (Stewart, 1994).

A possible alternative interaction is revealed by the demonstration that LIF receptors are expressed on human trophoblast and decidual leucocytes are a major source of LIF. This finding, together with the finding that LIF stimulates chorionic gonadotrophin production by trophoblast (Sawai et al., 1995), indicates that LIF is an essential mediator between maternal decidua and invading trophoblast (Sharkey et al., 1999).

\section{Interleukin 1 and interleukin 1-like receptors}

If one cytokine was to be singled out as having the widest impact, IL-1 would be a strong contender. IL-1 has an effect on many cell types and has crucial roles in haematopoiesis acute-phase protein expression and kidney function. It is perhaps surprising that the knockout mouse with deleted type 1 receptor (the only functional receptor) is viable and reportedly fertile (Abbondanzo et al., 1996). In addition, mice deficient in IL-1 $\beta$ (Zheng et al., 1995) and IL-1ß-converting enzyme (Kuida et al., 1995; Li et al., 1995) are also fertile. Although redundancies can be invoked as an explanation, the survival of these mice is not fully understood at present and substitutes would have to cover a wide range of IL- 1 activities within the uterus (Table 2). Compounds such as IL-18 (IFN- $\boldsymbol{\gamma}$-inducing factor) are similar to IL-1, and the IL-18 receptor was previously known as IL-1 receptor-like protein.

In non-reproductive systems, IL-1 frequently acts in a synergistic fashion with other cytokines. Synergistic action of IL-1 with TNF- $\alpha$ has been observed for IL-8 (Matsushima and Oppenheim, 1989) and PGE production (Dinarello, 1992; Fujishima et al., 1993) and similar synergistic induction of COX-2 has also been reported (Bry and Hallman, 1991). IL-1 amplifies the effect of bradykinin in stimulating PGE (Angel et al., 1994), a pathway that is important in pain transmission by either $\mathrm{PGE}_{2}$ or $\mathrm{PGI}_{2}$ 
Table 2. Effects of interleukin 1 (IL-1) on endometrium

\begin{tabular}{|c|c|c|}
\hline & Effect & Reference \\
\hline TNF- $\alpha$ & TNF- $\alpha$ is stimulated by IL- 1 . & Laird et al., 1996 \\
\hline IL-8 & mRNA for IL-8 is stimulated by IL- 1 . & Arici et al., 1996 \\
\hline LIF & TNF $\alpha$ and IL-1 induce mRNA for LIF. & $\begin{array}{l}\text { Arici et al., 1995; } \\
\text { Knight et al., } 1999\end{array}$ \\
\hline MMP-1 & IL-1 $\alpha$ from epithelium stimulates stromal fibroblast production of MMP-1. & Singer et al., 1999 \\
\hline MMP-9 & $\begin{array}{l}\text { IL- } 1 \beta \text { raises mRNA for MMP-9 and reduces that for TIMP- } 1 \text { and TIMP-3 in } \\
\text { endometrium. IL- } 1 \alpha \text { raises MMP-9 activity in trophoblast. }\end{array}$ & $\begin{array}{l}\text { Huang et al., 1998; } \\
\text { Meissner et al., } 1999\end{array}$ \\
\hline Apoptosis & $\begin{array}{l}\text { Susceptibility to apoptosis in epithelial cells is blocked by IL-1 receptor } \\
\text { antagonist. }\end{array}$ & Tanaka, et al., 1998 \\
\hline Integrins & IL-1 receptor antagonist reduces levels of $\alpha-4, \alpha-5$ and $\beta-3$ integrins. & Simon et al., 1998 \\
\hline f-Fibronectin & Stimulated by IL-1 in fibroblasts (also stimulated by TGF $\beta$ ). & Meissner et al., 1999 \\
\hline COX-2 & $\begin{array}{l}\text { In an endometrial epithelial cell line, IL- } 1 \alpha \text { stimulated } \mathrm{PGE}_{2} \text { and } \mathrm{PGF}_{2 \alpha} \text {. } \\
\text { COX-1 remained constant. }\end{array}$ & $\begin{array}{l}\text { Jacobs et al., 1994; } \\
\text { Kniss et al., } 1997\end{array}$ \\
\hline SIICAM-1 & $\begin{array}{l}\text { IL-1 } 1 \beta \text { increases soluble ICAM - a possible immunomodulatory pathway since } \\
\text { ICAM is necessary for initial adhesion before leukocyte passage through vessel } \\
\text { walls. }\end{array}$ & Vigano et al., 1998 \\
\hline EP1 & This prostaglandin receptor is increased in the amnion in response to IL-1 $\beta$. & Spaziani et al., 1997 \\
\hline IL-6 & Raised in the secretory phase. Stimulated by IL- $1 \beta$ specifically in stromal cells. & $\begin{array}{l}\text { Tseng et al., 1996; } \\
\text { Vandermolen and } \\
\text { Gu, } 1996\end{array}$ \\
\hline Steroids from trophoblast & Monocyte IL-1 and TNF $\alpha$ modulate trophoblast steroid synthesis. & Feinberg et al., 1994 \\
\hline
\end{tabular}

COX, cyclooxygenase; EP, prostaglandin E receptor; SIICAM, soluble intercellular adhesion molecule; IL-8, interleukin 8; LIF, leukaemia inhibitory factor; MMP, matrix metalloproteinase; PG, prostaglandin; TGF $\beta$, transforming growth factor $\beta$; TNF- $\alpha$, tumour necrosis factor $\alpha$.

(Murata et al., 1997). Other subtle interactions are seen with IL-1 since macrophages primed with IFN- $\gamma$ have a reduced COX-2 expression after IL-1 treatment (BarriosRodiles and Chadee, 1998).

IL-1 stimulates production of MCP-1, a compound that is both chemotactic and a modulator associated with the Th-1-Th-2 dichotomy (Chensue et al., 1996) and these effects are enhanced by IL- 4 and IFN- $\gamma$, although no such increase is seen with TNF- $\alpha$ stimulation (Seitz et al., 1994). IL-1 has major effects on endothelial cells, affecting prostaglandins and intercellular adhesion molecule 1 (ICAM-1), IL-1, IL-6 and MHC expression. Many of the effects of IL-1 in the uterus involve endothelial cells (Table 2). Notwithstanding the fertility of mice with deletions in the IL-1 pathway, some studies indicate that intraperitoneal injection of IL-1ra prevents implantation (Simon et al., 1998), although others indicate that the receptor antagonist has no effect (Abbondanzo et al., 1996). Simon et al. (1998) reported that, where implantation is prevented by IL-1 receptor antagonist, it is due to a disturbance of the integrin expression on the epithelial cell surface (Simon et al., 1998).

IL-1 is present in the uterus throughout the menstrual cycle and therefore is unlikely to be directly modulated by progesterone. Such an expression pattern is consistent with a controlling function in both epithelial and endothelial cells and thus may not be directly related to implantation or the early stages of menstruation.

\section{Transforming growth factor $\beta$ S}

TGF $\beta$ is a regulator of growth and differentiation but the role it plays in endometrial physiology is not clear, although TGF $\beta$ s 1-3 are implicated in the process of decidualization (Ando et al., 1998). TGF $\beta$ s are produced and released from cells as inactive precursors that are dependent on proteolytic activation for full activity. The exact mechanisms of activation are uncertain but urokinase type plasminogen activator (UPA) and cathepsin D are competent activators (Lyons et al., 1988). TGF $\beta$ is likely to be short-lived in vivo because of its rapid binding to $\alpha 2$ macroglobulin.

Four TGF $\beta$ s (1-4) have been reported in endometrium (Chegini et al., 1994; Tabibzadeh et al., 1998) and, although they play an immunosuppressive role in decidua (Lea et al., 1992), there is some doubt about whether the 


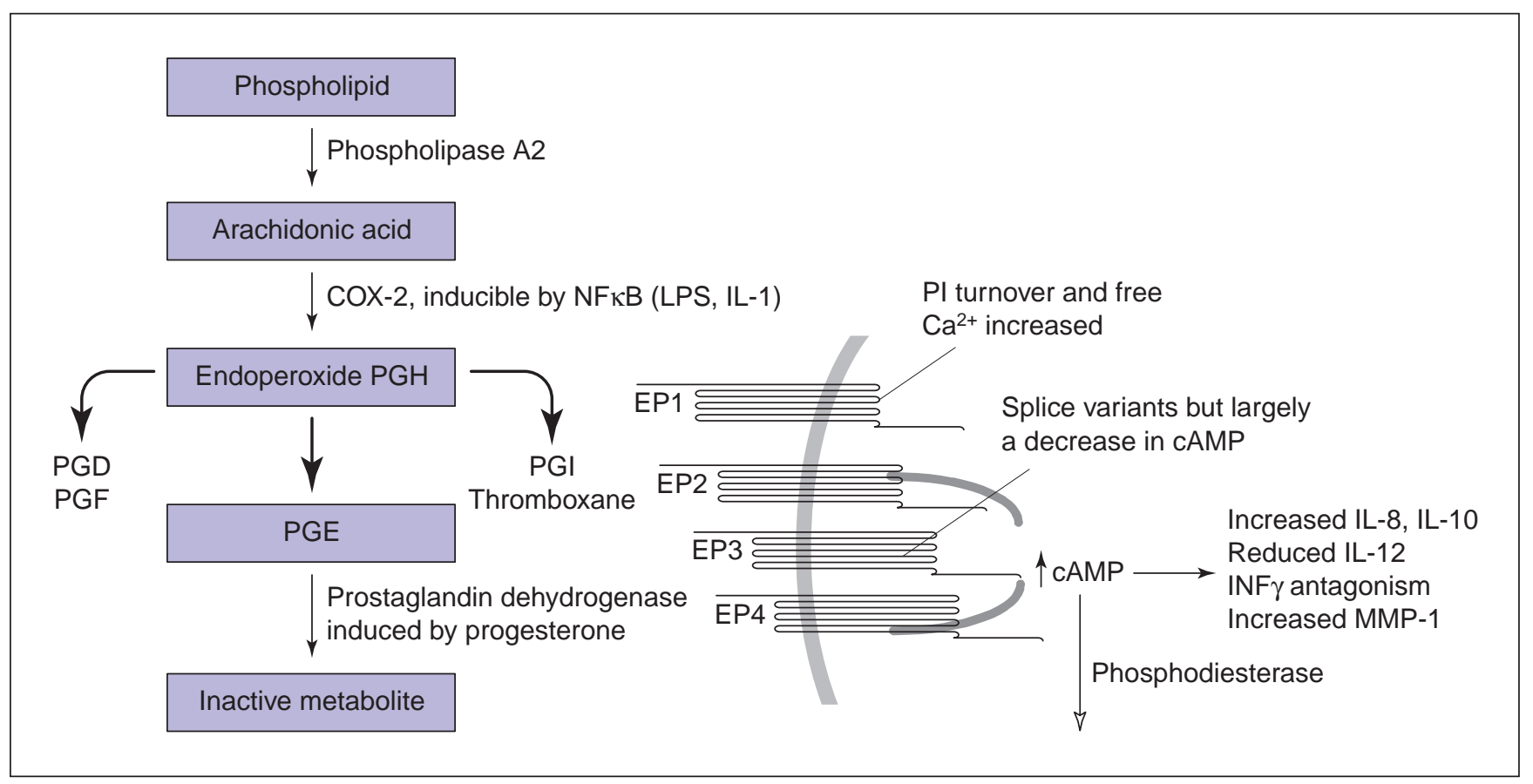

Fig. 5. The pathways of prostaglandin (PG) action. Control can be exercised at several stages: phospholipase, cyclo-oxygenase, prostaglandin dehydrogenase or even prostaglandin receptor expression. COX: cyclooxygenase IL, interleukin; INF, interferon. LPS: lipopolysaccharide; MMP: matrix metalloproteinase.

latent forms are converted to active forms before the decrease in progesterone at the end of the menstrual cycle allows the upregulation of proteases such as UPA (Sandberg et al., 1998).

Several actions of TGF $\beta$ are associated with the control of agents affecting ECM. TGF $\beta$ stimulates both the plasminogen activator uPA (Sandberg et al., 1998) and the uPA inhibitor PAI (Sandberg et al., 1997). MMPs and their inhibitors (TIMPS) are also affected, and TGF $\beta$ is thought to mediate the effect of progesterone in suppressing matrilysin (MMP-7) in endometrial epithelial cells (Bruner et al., 1995) although in stromal cells the evidence so far is that a similar effect is mediated by an increase in TIMPs 1 and 3 (Huang et al., 1998).

Effects of TGF $\beta$ on endometrial growth have been reported, with stromal cell growth stimulated in studies in vitro (Marshburn et al., 1994; Tang et al., 1994). The effect of progesterone in stimulating TGF $\beta$ (Bruner et al., 1995) is of interest since it identifies one mechanism by which stromal cells (which retain progesterone receptors in the secretory phase) can influence glandular epithelium from which progesterone receptors are lost in the second half of this phase of the menstrual cycle.

TGF $\beta$ 1, together with IL-10 and $\mathrm{PGE}_{2}$, is one of the main suppressive molecules secreted by the macrophage (Bogdan et al., 1992). Many properties of PGE and TGF $\beta$ are similar and their exact interaction has yet to be established. TGF $\beta$ and PGE may both promote tolerance for trophoblast antigen in decidua and if this occurs their action would be similar to their action in gut, where oral tolerance, the essential accommodation of food antigen, is dependent on local 'suppressive' cytokine secretion (Groux et al., 1997; MacDonald, 1999; Newberry et al., 1999).

\section{Prostaglandins}

Prostaglandins have several actions relevant to cytokines and menstrual dysfuction since they are involved in both the initiation of menstruation and in pain associated with menstruation. Prostaglandins have an hyperalgesic effect, accentuating cytokine actions at nociceptors (Ferreira et al., 1973). Thus, the analgesic effects of nonsteroidal anti-inflammatory drugs (NSAIDs) can be understood in the context of the two-mediator hypothesis, which impinges on many prostaglandin effects (Williams and Morley, 1973). A study in which the prostacyclin (PGI) receptor was ablated in mice showed that such animals had a higher pain threshold (Murata et al., 1997) and, although little PGI is synthesized in human endometrium (Abel and Kelly, 1979), this effect might be relevant to menstrual pain originating in myometrium, where PGI is the major prostaglandin.

Prostaglandins are involved in the control of cytokine release, cell growth, differentiation and vasoactive effects. It is probably this vasoactive proinflammatory action that accounts for the anti-inflammatory action of aspirin, ibuprofen and fenamates such as mefenamic acid (Ponstan). Mefenamic acid is widely used for the 
management of menstrual problems (menorrhagia and dysmenorrhoea) and although part of the action is undoubtedly analgesic, effects on blood loss have been acknowledged (Guillebaud et al., 1978; Cameron et al., 1987; Bonnar and Sheppard, 1996). These effects are thought to be due to the vasoactive properties of both $\mathrm{PGE}_{2}$ and $\mathrm{PGF}_{2 \alpha}$. There is an increasing awareness that not all NSAID effects are mediated through the cyclooxygenase pathway (Shiff and Rigas, 1999; Zhang et al., 1999) and therefore other possibilities, such as the action of the peroxisome proliferator (PPAR) and other nuclear receptors, ought to be considered.

Since the early studies of Pickles (1967), prostaglandins have been implicated in the mechanism of menstruation and subsequent findings have supported this tenet (Baird et al., 1996). However, neither the relative contributions of COX-1 and COX-2 nor the location and the types of the prostaglandin receptors in human endometrium are known at present. Prostaglandins are also involved in implantation (for review, see Psychoyos et al., 1995) and the critical role of cyclo-oxygenase has also been demonstrated by gene ablation studies (Table 2).

Prostaglandin synthesis involves the control of free substrate (arachidonic acid) concentrations by the modulation of phospholipase, control of inducible cyclo-oxygenase (COX-2) and control of the catabolic enzyme PG-15dehydrogenase (Fig. 5). In addition, enzymes convert the common intermediate endoperoxide $\left(\mathrm{PGH}_{2}\right)$ to the individual prostaglandins, although it has been suggested that synthesis of endoperoxide by COX-2 leads mainly to $\mathrm{PGE}_{2}$ and $\mathrm{PGI}_{2}$ (Brock et al., 1999).

Prostaglandins act on heptahelical G-protein-coupled receptors, which for PGE can be of at least four types (EP1-EP4) (Fig. 5). Although prostaglandins act on cell surface receptors, they are also synthesized by COX-1 and COX-2 at the nuclear membrane and are found on both the inner and outer surfaces of this membrane, indicating a nuclear action (Spencer et al., 1998). The COX enzymes are associated with cell membranes but do not have transmembrane sequences. They attach to one face of the membrane by four short $\alpha$-helices. Nuclear actions have been proposed for some prostaglandin derivatives such as those related to a dehydration form of PGD (PGJ), which interacts with the PPAR- $\gamma$ receptor.

In addition to the above evidence of the action of prostaglandin inhibitors, there are other factors implicating prostaglandins in menstruation. In anovular women, whose endometrium is influenced by oestradiol but not progesterone, the production of prostaglandin is negligible in biopsies but synthesis is seen when the substrate arachidonic acid is made available (Smith et al., 1982). This finding indicates that the ability to provide precursor is progesterone dependent. However, some actions of prostaglandin may not be possible under the influence of progesterone since release in culture is attenuated (Abel and Baird, 1980). Prostaglandin dehydrogenase (PGDH) provides strong catabolizing activity (Casey et al., 1980), which may account for some of the reduction. Greenland et al. (2000) have shown that PGDH is progesteronedependent in reproductive tissues. Progesterone may also inhibit the inducible synthesis of COX-2 in endometrium (Bracken et al., 1997; Critchley et al., 1999) and decidua (Ishihara et al., 1995). Since COX-2 can be induced via the NFkB pathway (Fig. 3), this may be a major point of action of progesterone (Kalkhoven et al., 1996).

Thus, progesterone withdrawal is a stimulus to prostaglandin production in certain microenvironments, for example, in early decidua, where prostaglandin dehydrogenase becomes undetectable and PGE is clearly evident in the cells surrounding the small blood vessels (Cheng et al., 1993a,b). Towards the end of the menstrual cycle, there is a physiological withdrawal of progesterone and again COX-2 expression is increased at this location (Jones et al., 1997).

The COX-2-deficient mouse has defective decidualization and implantation (Lim et al., 1997) and other knockout mice, such as HOX-10-deficient knockout mice, have a deficiency in the progesterone control of prostaglandin receptors (Lim et al., 1999b). These findings indicate an important role for prostaglandins in implantation as well as in decidualization. Decidualization is a cAMP-dependent process and, in experiments in vitro, PGE enhances decidualization (Frank et al., 1994). The process is mediated by COX-2 in vivo (Han et al., 1996) but progesterone is also essential and combinations of progesterone and CAMPincreasing mediators are effective in inducing decidualization in vitro (Brosens et al., 1999). The cAMP would by-pass any PGE effect since PGE interacts with EP2 or EP4 receptors to give an increased intracellular cAMP concentration. However, for implantation, the evidence is strongest for a role in implantation for COX-2 rather than for PGE and it has been suggested that prostacyclin is the key prostaglandin interacting with nuclear PPAR $\delta$ ( Lim et al., 1999b) although, in NIH 3 T3 cells at least, the main product from activation of nuclear COX-2 is PGE (Spencer et al., 1998). In women, the synthesis of $\mathrm{PGI}_{2}$ and therefore its involvement in implantation is less likely since human endometrium produces very little of this prostaglandin (Abel and Kelly, 1979).

Cytokines such as IL-1 and TNF- $\alpha$ stimulate prostaglandin production, and PGE is a major inhibitor of lipopolysaccharide-induced IL-1 production by monocytes (Kunkel et al., 1986) and thus a negative feedback regulation of immune responses in such cells is apparent. PGE is involved in stimulating MMP production (Lindsey et al., 1996; Zeng et al., 1996; Shankavaram et al., 1997), stimulation of IL-8 and IL-10 production (Strassmann et al., 1994; Agro et al., 1996; Denison et al., 1999), antibody class switching in B cells (Phipps et al., 1991; Roper et al., 1990) and inhibition of IL-12 synthesis from activated monocytes (Kraan et al., 1995). All of these properties of PGE are consistent with the damping of any Th-1 (cellmediated) response within decidua, where a major source of PGE would be the trophoblast (Kelly et al., 1995). The 
suppression of IL-12 is important since it has been shown to activate maternal lymphocytes (both peripheral and decidual) to attack trophoblast (Hayakawa et al., 1999).

\section{Chemokines}

Chemokines are chemotactic cytokines of 8-10 kDa that are classified by their distribution of cysteines. These compounds have similarities in gene sequence, protein sequence and tertiary structure. There are two critical cysteine bonds with either one ( $\alpha$ - or CXC (cystein-any amino acid-cysteine) chemokines) or no ( $\beta$ - or CC (cysteine-cysteine) chemokines) amino acids separating the $\mathrm{N}$ terminal cysteines. A further group (fraktalkines) has three amino acids (CX3C) separating the $\mathrm{N}$-terminal cysteines. The individual classes can be further subdivided: in the $\alpha$ group, those with a ELR (Glu-Leu-Arg) motif next to the cysteine nearest the $\mathrm{N}$-terminus, primarily attract neutrophils. Chemokines not only attract cells but also activate them and contribute to angiogenesis and haematopoiesis. Activation may depend on cell type and $\beta$-chemokines such as MCP-1 skew T-cell populations into a Th-2 (humoral response pattern of cytokine release) as opposed to a Th-1 (cell-mediated) response (Chensue et al., 1996). The MCP-1 -/- mouse has been used to demonstrate an absolute necessity for MCP-1 in mounting a Th2 response $(\mathrm{Gu}$ et al., 2000). Some chemokines can selectively attract haematopoietic progenitor cells out of bone marrow, for example, during inflammatory events and thus locally derived decidual signals may attract leucocytes to decidua.

The presence of the $\alpha$-chemokine IL- 8 and the $\beta$ chemokine MCP-1 have been demonstrated in perivascular cells (Critchley et al., 1994b, 1999; Jones et al., 1997) and the mRNA and protein for these chemokines increase perimenstrually, indicating a role in the early stages of menstruation (Critchley et al., 1999; Milne et al., 1999). Eotaxin, an eosinophil chemotactic agent, has also been identified in a perivascular location in the late secretory phase of the cycle (Zhang et al., 2000). In human endometrium, chemokines may also be responsible for the increasing number of monocytes in the second half of the menstrual cycle (Kamat and Isaacson, 1987).

Epithelial cells act as both a physical barrier to and a target for infection in endometrium. Thus, these cells must possess a competent response to infection, and the uterine epithelium is a source of several chemokines such as MCP-1 (Jolicoeur et al., 1998), macrophage inflammatory protein $1 \alpha(\mathrm{MIP}-1 \alpha)$ (Akiyama et al., 1999) regulatedupon-activation, normal T cell expressed and presumably secreted (RANTES) (Altman et al., 1999) and eotaxin (Zhang et al., 2000), although here their primary role may be to participate in any immune defences raised against infection. Expression of MCP-1 in glandular cells is particularly noticeable in endometriotic tissue (Jolicoeur et al., 1998) or in tissue that is otherwise stimulated. RANTES is also produced by endometrial stromal cells and its synthesis is enhanced by lipopolysaccharide, TNF and IL-1
(Arima et al., 2000). This effect of lipopolysaccharide indicates that these cells also can recognize infectious agents.

\section{Conclusions}

Menstruation has been shown to involve cytokines and MMPs and is initiated by the decrease in the circulating concentrations of ovarian progesterone. However, the first stages in menstruation are not clear and the cells that first respond to the decrease in progesterone have not been identified. Many of the vasoconstricting agents that may affect blood loss during menstruation (for example, endothelins and prostaglandins) are produced mainly in the glandular epithelium, a site not obviously relevant to the blood vessels. Attention may now have to be directed to the cells immediately surrounding the spiral arterioles. These cells have been shown to respond to progesterone and are potent sources of cytokines and prostaglandin. Moreover, these cells appear to possess components of the CD40 signalling system, which exerts control over cytokine production in cells as diverse as B cells and fibroblasts. Concentration on such signalling pathways over the next decade may result in a new approach to the control of endometrial function that will allow better medical intervention in distressing complaints such as dysmenorrhoea and menorrhagia.

\section{References}

Key references are identified by asterisks.

Abberton KM, Taylor NH, Healy DL and Rogers PA (1999) Vascular smooth muscle cell proliferation in arterioles of the human endometrium Human Reproduction 14 1072-1079

Abbondanzo SJ, Cullinan EB, McIntyre K, Labow MA and Stewart CL (1996) Reproduction in mice lacking a functional type 1 IL-1 receptor Endocrinology 137 3598-3601

Abel MH and Baird DT (1980) The effect of $17 \beta$ estradiol and progesterone on prostaglandin production by human endometrium maintained in organ culture Endocrinology 106 1599-1606

Abel MH and Kelly RW (1979) Differential production of prostaglandins within the human uterus Prostaglandins 18 821-828

Agro A, Langdon C, Smith F and Richards CD (1996) Prostaglandin E(2) enhances interleukin-8 (II-8) and IL-6 but inhibits GMCSF production by IL-1 stimulated human synovial fibroblasts in vitro. Journal of rheumatology 23 862-868

Akiyama M, Okabe H, Takakura K, Fujiyama Y and Noda Y (1999) Expression of macrophage inflammatory protein-1alpha (MIP-1alpha) in human endometrium throughout the menstrual cycle British Journal of Obstetrics and Gynaecology 106 725-730

Altman GB, Gown AM, Luchtel DL and Baker C (1999) RANTES production by cultured primate endometrial epithelial cells American Journal of Reproductive Immunology 42 168-174

Ando N, Hirahara F, Fukushima J, Kawamoto S, Okuda K, Funabashi T, Gorai I and Minaguchi H (1998) Differential gene expression of TGF- $\beta$ isoforms and TGF- $\beta$ receptors during the first trimester of pregnancy at the human maternal-fetal interface American Journal of Reproductive Immunology 40 48-56

Angel J, Audubert F, Bismuth G and Fournier C (1994) IL-1 $\beta$ amplifies bradykinin-induced prostaglandins E2 production via a phospholipase D-linked mechanism Journal of Immunology 1525032

Aplin JD (1997) Adhesion molecules in implantation Reviews of Reproduction 2 84-93

Arici A, Engin O, Attar E and Olive DL (1995) Modulation of leukemia 
inhibitory factor gene expression and protein biosynthesis in human endometrium Journal of Clinical Endocrinology and Metabolism 80, 1908-1915

Arici A, Macdonald PC and Casey ML (1996) Progestin regulation of interleukin-8 messenger-RNA levels and protein-synthesis in human endometrial stromal cells Journal of Steroid Biochemistry and Molecular Biology 58 71-76

Arima K, Nasu K, Narahara H, Fujisawa K, Matsui N and Miyakawa I (2000) Effects of lipopolysaccharide and cytokines on production of RANTES by cultured human endometrial stromal cells Molecular Human Reproduction 6 246-251

Baird DT, Cameron ST, Critchley HO, Drudy TA, Howe A, Jones RL, Lea RG and Kelly RW (1996) Prostaglandins and menstruation European Journal of Obstetrics and Gynecology and Reproductive Biology 70 15-17

Baldwin AS (1996) The NF-kappa B and I kappa B proteins: new discoveries and insights Annual Review of Immunology 14 649-683

Barrios-Rodiles M and Chadee K (1998) Novel regulation of cyclooxygenase 2 expression and prostaglandin E-2 production by IFN-gamma in human macrophages Journal of Immunology 161 2441-2448

Bell SC (1979) Immunochemical identity of 'decidualization-associated protein' and alpha 2 acute-phase macroglobulin in the pregnant rat Journal of Reproductive Immunology 1 193-206

Benson GV, Lim H, Paria BC, Satokata I, Dey SK and Maas RL (1996) Mechanisms of reduced fertility in Hoxa-10 mutant mice: uterine homeosis and loss of maternal Hoxa-10 expression Development 122 2687-2696

Bilinski P, Roopenian D and Gossler A (1998) Maternal IL-11Ralpha function is required for normal decidua and fetoplacental development in mice Genes and Development 12 2234-2243

Bogdan C, Paik J, Vodovotz Y and Nathan C (1992) Contrasting mechanisms for suppression of macrophage cytokine release by TGF $\beta$ and IL-10 Journal of Biological Chemistry 26723 301-23 308

Bole-Feysot C, Goffin V, Edery M, Binart N and Kelly PA (1998) Prolactin (PRL) and its receptor: actions signal transduction pathways and phenotypes observed in PRL receptor knockout mice Endocrine Reviews 19 225-268

Bonnar J and Sheppard BL (1996) Treatment of menorrhagia during menstruation: randomised controlled trial of ethamsylate mefenamic acid and tranexamic acid British Medical Journal 313 579-582

Bourke E and Moynagh PN (1999) Antiinflammatory effects of glucocorticoids in brain cells independent of NF-kappa B Journal of Immunology $1632113-2119$

Bracken KE, Elger W, Jantke I, Nanninga A and Gellersen B (1997) Cloning of guinea pig cyclooxygenase-2 and 15-hydroxyprostaglandin dehydrogenase complementary deoxyribonucleic acids: steroidmodulated gene expression correlates to prostaglandin F2 alpha secretion in cultured endometrial cells Endocrinology 138 237-247

Brock TG, McNish RW and Peters-Golden M (1999) Arachidonic acid is preferentially metabolized by cyclooxygenase- 2 to prostacyclin and prostaglandin $E_{2}$ Journal of Biological Chemistry 274 11 660-11666

*Brosens JJ, Hayashi N and White JO (1999) Progesterone receptor regulates decidual prolactin expression in differentiating human endometrial stromal cells Endocrinology 140 4809-4820

Bruner KL, Rodgers WH, Gold LI, Korc M, Hargrove JT, Matrisian LM and Osteen KG (1995) Transforming growth factor- $\beta$ mediates the progesterone suppression of an epithelial metalloproteinase by adjacent stroma in the human endometrium Proceedings National Academy of Sciences USA 92 7362-7366

Bry K and Hallman M (1991) Synergistic stimulation of amnion cell prostaglandins E2 synthesis by interleukin-1 tumor necrosis factor and products from activated human granulocytes Prostaglandins leukotrienes and essential fatty acids 44 241-245

Buckley CH and Fox H (1989) Biopsy Pathology of the Endometrium pp 38-47 Chapman and Hall, London

Buhimschi I, Ali M, Jain V Chwalisz K and Garfield RE (1996) Differential regulation of nitric oxide in the rat uterus and cervix during pregnancy and labour Human Reproduction 11 1755-1766

Caldenhoven E, Liden J, Wissink S, Vandestolpe A, Raaijmakers J, Koenderman L, Okret S, Gustafsson JA and Vandersaag PT (1995)
Negative cross-talk between RelA and the glucocorticoid receptor - a possible mechanism for the antiinflammatory action of glucocorticoids Molecular Endocrinology 9 401-412

Cameron IT, Leask R, Kelly RW and Baird DT (1987) The effect of danazol mefenamic acid norethisterone and a progesterone impregnated coil on endometrial prostaglandin concentrations in women with menorrhagia Prostaglandins 34 99-110

Cameron ST, Critchley HOD, Buckley H, Kelly RW and Baird DT (1996) Effects of Mifepristone and Onapristone on the development by the human endometrium of progesterone-depedent factors (leukemia inhibitory factor prostaglandin dehydrogenase and glycodelin) of potential importance for implantation Human Reproduction 1 40-49

Campbell S and Cameron IT (1998) The origins and physiology of menstruation. In Clinical Disorders of the Endometrium and the Menstrual Cycle pp 13-30 Eds IT Cameron, IS Fraser and SK Smith. Oxford University Press, Oxford

Carter AM (1997) When is the maternal placental circulation established in man? Placenta 18 83-87

Casey ML, Hemsell DL, MacDonald PC and Johnston JM (1980) NAD+dependent 15-hydroxyprostaglandin dehydrogenase activity in human endometrium Prostaglandins 19 115-122

Challis JRG and Mitchell BF (1988) Steroid production by the fetal membranes in relation to the onset of parturition. In The Onset of Labor: Cellular and Integrative Mechanisms pp 233-253 Eds D McNellis et al. Perinatology Press, Ithaca, NY

Chegini N, Zhao Y, Williams RS and Flanders KC (1994) Human uterine tissue throughout the menstrual cycle expresses transforming growth factor- $\beta 1$ (TGF $\beta 1$ ) TGF $\beta 2$ TGF $\beta 3$ and TGF $\beta$ type II receptor messemger ribonucleic acid and protein and contains [125I] TGF $\beta 1$-binding sites Endocrinology 135 439-449

Chen GA, Huang JR and Tseng L (1988) The effect of relaxin on cyclic adenosine $3^{\prime} 5^{\prime}$-monophosphate concentrations in human endometrial glandular epithelial cells Biology of Reproduction 39 519-525

Cheng L, Kelly RW, Thong KJ, Hume R and Baird DT (1993a) The effect of mifepristone (RU486) on the immunohistochemical distribution of prostaglandin $\mathrm{E}$ and its metabolite in decidual and chorionic tissue in early pregnancy Journal of Clinical Endocrinology and Metabolism 77 873-877

Cheng L, Kelly RW, Thong KJ, Hume R and Baird DT (1993b) The effects of mifepristone (RU486) on prostaglandin dehydrogenase in decidual and chorionic tissue in early pregnancy Human Reproduction 8 705-709

Chensue SW, Warmington KS, Ruth JH, Sanghi PS, Lincoln P and Kunkel SL (1996) Role of monocyte chemoattractant protein-1 (MCP-1) In Th1 (mycobacterial) and Th2 (schistosomal) antigen-induced granuloma formation - relationship to local inflammation Th cell expression and IL-12 production Journal of Immunology 157 4602-4608

Chwalisz K, Winterhager E, Thienel T and Garfield RE (1999) Synergistic role of nitric oxide and progesterone during the establishment of pregnancy in the rat Human Reproduction 14 542-552

Cohen PE, Nishimura K, Zhu L and Pollard JW (1999) Macrophages: important accessory cells for reproductive function Journal of Leukocyte Biology 66 765-772

Colditz IG (1990) Effect of exogenous prostaglandin $E_{2}$ and actinomycin D on plasma leakage induced by neutrophil activating peptide-1/ interleukin-8 Immunology and Cell Biology 68 397-403

Critchley HOD and Healy DL (1998) Effects of estrogen and progesterone on the endometrium. In Estrogens and Progestogens in Clinical Practice pp 145-161 Eds IS Fraser et al. Churchill Livingstone, Edinburgh

Critchley HO, Abberton KM, Taylor NH, Healy DL and Rogers PA (1994a) Endometrial sex steroid receptor expression in women with menorrhagia British Journal of Obstetrics and Gynaecology 101 428-434

Critchley HOD, Kelly RW and Kooy J (1994b) Perivascular expression of chemokine interleukin-8 in human endometrium Human Reproduction 9 1406-1409

*Critchley HO, Kelly RW, Lea RG, Drudy TA, Jones RL and Baird DT (1996) Sex steroid regulation of leukocyte traffic in human decidua Human Reproduction 11 2257-2262 
Critchley HO, Jones RL, Lea RG, Drudy TA, Kelly RW, Williams AR and Baird DT (1999) Role of inflammatory mediators in human endometrium during progesterone withdrawal and early pregnancy Journal of Clinical Endocrinology and Metabolism 84 240-248

Das SK, Lim H, Paria BC and Dey SK (1999) Cyclin D3 in the mouse uterus is associated with the decidualization process during early pregnancy Journal of Molecular Endocrinology 22 91-101

Delhase M, Hayakawa M, Chen Y and Karin M (1999) Positive and negative regulation of IkappaB kinase activity through IKKbeta subunit phosphorylation Science 284 309-313

Denison FC, Grant VE, Calder AA and Kelly RW (1999) Seminal plasma components stimulate interleukin-8 and interleukin-10 release Molecular Human Reproduction 5 220-226

DiDonato JA, Hayakawa M, Rothwarf DM, Zandi E and Karin M (1997) A cytokine-responsive IkappaB kinase that activates the transcription factor NF-kappaB Nature 388 548-554

Dinarello CA (1992) Role of interleukin-1 and tumor necrosis factor in systemic responses to infection and inflammation. In Inflammation: Basic Principles and Clinical Correlates pp 211-232 Eds JI Gallin et al. Raven Press, New York

Egidy G, Juillerat-Jeanneret L, Korth P, Bosman FT and Pinet F (2000) The endothelin system in normal human colon American Journal of Physiology of the Gastrointestinal Tract and Liver Physiology 279 G211-G222

Ehring GR, Kerschbaum HH, Eder C, Neben AL, Fanger CM, Khoury RM, Negulescu P and Cahalan MD (1998) A nongenomic mechanism for progesterone-mediated immunosuppression: inhibition of $\mathrm{K}^{+}$channels $\mathrm{Ca}^{2+}$ signaling and gene expression in $\mathrm{T}$ lymphocytes Journal of Experimental Medicine 188 1593-1602

Feinberg BB, Anderson DJ, Steller MA, Fulop V, Berkowitz RS and Hill JA (1994) Cytokine regulation of trophoblast steroidogenesis Journal of Clinical Endocrinology and Metabolism 78 586-591

Ferenczy A, Bertrand G and Gelfand MM (1979) Proliferation kinetics of human endometrium during the normal menstrual cycle American Journal of Obstetrics and Gynecology 133 859-867

Ferreira SH, Moncada S and Vane JR (1973) Prostaglandins and the mechanism of analgesia produced by aspirin-like drugs British Journal of Pharmacology 49 86-97

Finn CA (1986) Implantation menstruation and inflammation Biological Reviews 61 313-328

Foster SJ, Aked DM, Schroder JM and Christophers E (1989) Acute inflammatory effects of a monocyte-derived neutrophil activating peptide in rabbit skin Immunology 67 181-183

Frank GR Brar AK Cedars MI and Handwerger S (1994) Prostaglandin $E_{2}$ enhances human endometrial stromal cell differentiation Endocrinology 134 258-263

Frank GR, Brar AK, Jikihara H Cedars MI and Handwerger S (1995 Interleukin-1 beta and the endometrium: an inhibitor of stromal cell differentiation and possible autoregulator of decidualization in humans Biology of Reproduction 52 184-191

Fraser IS, McCarron G, Hutton B and Macey D (1987) Endometrial blood flow measured by xenon 133 clearance in women with normal menstrual cycles and dysfunctional uterine bleeding American Journal of Obstetrics and Gynecology 156 158-166

Fujimura M, Gasche Y, Morita-Fujimura Y, Massengale J, Kawase M and Chan PH (1999) Early appearance of activated matrix metalloproteinase- 9 and blood-brain barrier disruption in mice after focal cerebral ischemia and reperfusion Brain Research 842 92-100

Fujishima S, Hoffman AR, Vu T, Kim KJ, Zheng H, Daniel D, Kim Y, Wallace EF, Larrick JW and Raffin TA (1993) Regulation of neutrophil interleukin 8 gene expression and protein secretion by LPS TNF- $\alpha$ and IL-1 $\beta$ Journal of Cellular Physiology 154 478-485

Gannon BJ, Carati CJ and Verco CJ (1997) Endometrial perfusion across the normal human menstrual cycle assessed by laser Doppler fluxmetry Human Reproduction 12 132-139

Gendron RL, Paradis H, Hsieh-Li HM, Lee DW, Potter SS and Markoff E (1997) Abnormal uterine stromal and glandular function associated with maternal reproductive defects in Hoxa-11 null mice Biology of Reproduction 56 1097-1105
Goldberg MA and Schneider TJ (1994) Similarities between the oxygensensing mechanisms regulating the expression of vascular endothelial growth factor and erythropoietin Journal of Biological Chemistry 269 4355-4359

Grazzini E, Guillon G, Mouillac B and Zingg HH (1998) Inhibition of oxytocin receptor function by direct binding of progesterone Nature 392 509-512

*Greenland KJ, Jantke I, Jenatschke S, Bracken KE, Vinson C and Gellersen B (2000) The human NAD+-dependent 15-hydroxyprostaglandin dehydrogenase gene promoter is controlled by Ets and activating protein-1 transcription factors and progesterone Endocrinology 141 581-597

Groux H, O'Garra A, Bigler M, Rouleau M, Antonenko S, deVries JE and Roncarolo MG (1997) A CD4(+) T-cell subset inhibits antigen-specific T-cell responses and prevents colitis Nature 389 737-742

Gu L, Tseng S, Horner RM, Tam C, Loda M and JRB (2000) Control of Th polarization by the chemokine monocyte chemoattractant protein-1 Nature 404 407-410

Guillebaud J, Anderson ABM and Turnbull AC (1978) Reduction by mefenamic acid of increased menstrual blood loss associated with intrauterine contraception British Journal of Obstetrics and Gynaecology 85 53-62

Han SW, Lei ZM and Rao CV (1996) Up-regulation of cyclooxygenase-2 gene-expression by chorionic- gonadotropin during the differentiation of human endometrial stromal cells into decidua Endocrinology 137 1791-1797

Hanissian SH and Geha RS (1997) Jak3 is associated with CD40 and is critical for CD40 induction of gene expression in B cells Immunity $\mathbf{6}$ 379-387

Hayakawa S, Nagai N, Kanaeda T, Karasaki-Suzuki M, Ishii M, Chishima F and Satoh K (1999) Interleukin-12 augments cytolytic activity of peripheral and decidual lymphocytes against choriocarcinoma cell lines and primary culture human placental trophoblasts American Journal of Reproductive Immunology 41 320-329

Heo JH, Lucero J, Abumiya T, Koziol JA, Copeland BR and del Zoppo GJ (1999) Matrix metalloproteinases increase very early during experimental focal cerebral ischemia Journal of Cerebral Blood Flow and Metabolism $19624-633$

Hiemstra PS, Maassen RJ, Stolk J, Heinzelwieland R, Steffens GJ and Dijkman JH (1996) Antibacterial activity of antileukoprotease Infection and Immunity $\mathbf{6 4} 4520-4524$

Horwitz KB, Mockus MB and Lessey BA (1982) Variant T47D human breast cancer cells with high progesterone-receptor levels despite estrogen and antiestrogen resistance Cell 28 633-642

Huang HY, Wen Y, Irwin JC, Kruessel JS, Soong YK and Polan ML (1998) Cytokine-mediated regulation of 92-kilodalton type IV collagenase tissue inhibitor of metalloproteinase-1 (TIMP-1) and TIMP-3 messenger ribonucleic acid expression in human endometrial stromal cells Journal of Clinical Endocrinology and Metabolism 83 1721-1729

Ishihara O, Matsuoka K, Kinoshita K, Sullivan MH and Elder MG (1995) Interleukin-1 beta-stimulated PGE2 production from early first trimester human decidual cells is inhibited by dexamethasone and progesterone Prostaglandins 49 15-26

Ito A, Imada K, Sato T, Kubo T, Matsushima K and Mori Y (1994) Suppression of interleukin 8 production by progesterone in rabbit uterine cervix Biochemical Journal 301 183-186

Jacobs AL, Hwang D, Julian J and Carson DD (1994) Regulated expression of prostaglandin endoperoxide synthase- 2 by uterine stroma Endocrinology 135 1807-1815

Jolicoeur C, Boutouil M, Drouin R, Paradis I, Lemay A and Akoum A (1998) Increased expression of monocyte chemotactic protein-1 in the endometrium of women with endometriosis American Journal of Pathology 152 125-133

Jones RL, Kelly RW and Critchley HO (1997) Chemokine and cyclooxygenase-2 expression in human endometrium coincides with leukocyte accumulation Human Reproduction 12 1300-1306

*Kalkhoven E, Wissink S, Vandersaag PT and Vanderburg B (1996) Negative interaction between the relA(P65) subunit of NF- $\mathrm{KB}$ and the progesterone receptor Journal of Biological Chemistry 271 6217-6224

Kamat BR and Isaacson PG (1987) The immunocytochemical distribution 
of leukocytic subpopulations in human endometrium American Journal of Pathology 127 66-73

Karakurum M, Shreeniwas R, Chen J et al. (1994) Hypoxic induction of interleukin-8 gene-expression in human endothelial cells Journal of Clinical Investigation 93 1564-1570

Kariya M, Kanzaki H, Takakura K, Imai K, Okamoto N, Emi N, Kariya Y and Mori T (1991) Interleukin-1 inhibits in vitro decidualization of human endometrial stromal cells Journal of Clinical Endocrinology and Metabolism 73 1170-1174

Kelly JK and Fox H (1979) The local immunological defence system of the human endometrium Journal of Reproductive Immunology 1 39-45

Kelly RW, Illingworth P, Baldie G, Leask R, Brouwer S and Calder AA (1994) Progesterone control of interleukin-8 production in endometrium and chorio-decidual cells underlines the role of the neutrophil in menstruation and parturition Human Reproduction 9 253-258

Kelly RW, Carr GG, Elliot CL, Tulppala M and Critchley HOD (1995) Prostaglandin and cytokine release by trophoblastic villi: a potent suppressive profile Human Reproduction 10 3289-3292

Kelly RW, Carr GG and Riley SC (1997) The inhibition of synthesis of a $\beta$ chemokine monocyte chemotactic protein-1 (MCP-1) by progesterone Biochemical and Biophysical Research Communications 239 557-561

Kennedy TG (1980) Timing of uterine sensitivity for the decidual cell reaction: role of prostaglandins Biology of Reproduction 22 519-525

King A, Gardner L and Loke YW (1996) Evaluation of oestrogen and progesterone receptor expression in uterine mucosal lymphocytes Human Reproduction 11 1079-1082

*King AE, Critchley HOD and Kelly RW (2000) Presence of secretory leukocyte protease inhibitor in human endometrium and first trimester decidua suggests an antibacterial protective role Molecular Human Reproduction 6 191-196

King AE, Kelly RW, Critchley HOD, Malmstrom A, Sennstrom M and Phipps RP CD40 expression in uterine tisues: a key regulator of cytokine expression by fibroblasts Journal of Clinical Endocrinology and Metabolism (in press)

Kishimoto Y, Wada K, Nakamoto K, Ashida K, Kamisaki Y, Kawasaki H and Itoh T (1997) Quantitative analysis of cyclooxygenase-2 gene expression on acute gastric injury induced by ischemia-reperfusion in rats Life Sciences 60 L127-L133

Knight DA, Lydell CP, Zhou DY, Weir TD, Schellenberg RR and Bai TR (1999) Leukemia inhibitory factor (LIF) and LIF receptor in human lung distribution and regulation of LIF release American Journal of Respiratory Cell and Molecular Biology 20 834-841

Kniss DA, Zimmerman PD, Garver CL and Fertel RH (1997) Interleukin-1 receptor antagonist blocks interleukin-1-induced expression of cyclooxygenase-2 in endometrium American Journal of Obstetrics and Gynecology 177 559-567

Koji T, Chedid M, Rubin JS, Slayden OD, Csaky KG, Aaronson SA and Brenner RM (1994) Progesterone-dependent expression of keratinocyte growth factor mRNA in stromal cells of the primate endometrium: keratinocyte growth factor as a progestomedin Journal of Cell Biology 125 393-401

Kraan TCTMV, Boeije LCM, Smeenk RJT, Wijdenes J and Aarden LA (1995) Prostaglandin- $E_{2}$ is a potent inhibitor of human interleukin-12 production Journal of Experimental Medicine 181 775-779

Kuida K, Lippke JA, Ku G, Harding MW, Livingston DJ, Su MSS and Flavell RA (1995) Altered cytokine export and apoptosis in mice deficient in interleukin-1-beta converting-enzyme Science 267, 2000-2003

Kunkel SL, Chensue SW and Phan SH (1986) Prostaglandins as endogenous mediators of interleukin 1 production Journal of Immunology 136 186-192

Laird SM, Tuckerman EM, Saravelos H and Li TC (1996) The production of tumour necrosis factor alpha (TNF-alpha) by human endometrial cells in culture Human Reproduction 11 1318-1323

Lea RG, Flanders KC, Harley CB, Manuel J, Basnwatt D and Clark DA (1992) Release of a transforming growth factor (TGF)- $\beta 2$-related suppressor factor from postimplantation murine decidual tissue can be correlated with the detection of a subpopulation of cells containing RNA for TGF- 32 Journal of Immunology 148 778-787

Lee FS, Hagler J, Chen ZJ and Maniatis T (1997) Activation of the IkappaB alpha kinase complex by MEKK1, a kinase of the JNK pathway Cel/ $\mathbf{8 8}$ 213-222

Li P, Allen H, Banerjee S et al. (1995) Mice deficient in IL-1 $\beta$-converting enzyme are defective in production of mature IL-1 $\beta$ and resistant to endotoxic-shock Cell 80 401-411

Lim H, Paria BC, Das SK, Dinchuk JE, Langenbach R, Trzaskos JM and Dey SK (1997) Multiple female reproductive failures in cyclooxygenase 2-deficient mice Cell 91 197-208

Lim H, Gupta RA, Ma WG, Paria BC, Moller DE, Morrow JD, DuBois RN, Trzaskos JM and Dey SK (1999a) Cyclo-oxygenase-2-derived prostacyclin mediates embryo implantation in the mouse via PPARdelta Genes and Development 13 1561-1574

Lim H, Ma L, Ma WG, Maas RL and Dey SK (1999b) Hoxa-10 regulates uterine stromal cell responsiveness to progesterone during implantation and decidualization in the mouse Molecular Endocrinology 13 1005-1007

Lindsey JD, Kashiwagi K, Boyle D, Kashiwagi F, Firestein GS and Weinreb RN (1996) Prostaglandins increase proMMP-1 and proMMP-3 secretion by human ciliary smooth muscle cells Current Eye Research $\mathbf{1 5}$ 869-875

Liu ZG, Hsu H, Goeddel DV and Karin M (1996) Dissection of TNF receptor 1 effector functions: JNK activation is not linked to apoptosis while NF-kappaB activation prevents cell death Cell 87 565-576

Lockwood CJ, Krikun G, Hausknecht VA, Papp C and Schatz F (1998) Matrix metalloproteinase and matrix metalloproteinase inhibitor expression in endometrial stromal cells during progestin-initiated decidualization and menstruation-related progestin withdrawal Endocrinology 139 4607-4613

Loke YW and King A (1995) Human Implantation Cambridge University Press, Cambridge

Loke YW and King A (1996) Immunology of human implantation: an evolutionary perspective Human Reproduction 11 283-286

Luca M, Huang S, Gershenwald JE, Singh RK, Reich R and Bar-Eli M (1997) Expression of interleukin-8 by human melanoma cells upregulates MMP-2 activity and increases tumor growth and metastasis American Journal of Pathology 151 1105-1113

Lumsden MA, Brown A and Baird DT (1984) Prostaglandin production from homogenates of separated glandular epithelium and stroma from human endometrium Prostaglandins 28 485-496

Lydon JP, Demayo FJ, Funk CR, Mani SK, Hughes AR, Montgomery CA, Shyamala G, Conneely OM and Omalley BW (1995) Mice lacking progesterone receptor exhibit pleiotropic reproductive abnormalities Genes and Development 9 2266-2278

Lyons RM, Keski-Oja J and Moses HL (1988) Proteolytic activation of latent transforming growth factor-beta from fibroblast-conditioned medium Journal of Cell Biology 106 1659-1665

MacDonald TT (1999) Effector and regulatory lymphoid cells and cytokines in mucosal sites Current Topics in Microbiology and Immunology 236 113-135

McKay LI and Cidlowski JA (1999) Molecular control of immune/ inflammatory response: interactions between nuclear factor- $\mathrm{KB}$ and steroid receptor-signaling pathways Endocrine Reviews 20 435-439

Malinin NL, Boldin MP, Kovalenko AV and Wallach D (1997) MAP3Krelated kinase involved in NF-kappaB induction by TNF CD95 and IL-1 Nature 385 540-544

Markee JE (1940) Menstruation in intraocular endometrial transplants in the rhesus monkey Contributions to Embryology of the Carnegie Institution 177 211-308

Marshburn PB, Arici AM and Casey ML (1994) Expression of transforming growth factor-beta 1 messenger ribonucleic acid and the modulation of deoxyribonucleic acid synthesis by transforming growth factor-beta 1 in human endometrial cells American Journal of Obstetrics and Gynecology 170 1152-1158

Marzusch K, Buchholz F, Ruck P, Handgretinger R, Geiselhart A, Engelmann L and Dietl J (1997) Interleukin-12- and interleukin-2stimulated release of interferon-gamma by uterine CD56(++) large granular lymphocytes is amplified by decidual macrophages Human Reproduction 12 921-924

Matsushima K and Oppenheim JJ (1989) Interleukin 8 and MCAF: novel 
inflammatory cytokines inducible by $1 \mathrm{~L} 1$ and TNF Cytokine 1 2-13

Meissner A, Chardonnens D, Campana A and Bischof P (1999) Effects of tumour necrosis factor-alpha interleukin-1 alpha macrophage colony stimulating factor and transforming growth factor beta on trophoblastic matrix metalloproteinases Molecular Human Reproduction 5 252-260

Milne SA, Critchley HO, Drudy TA, Kelly RW and Baird DT (1999) Perivascular interleukin-8 messenger ribonucleic acid expression in human endometrium varies across the menstrual cycle and in early pregnancy decidua Journal of Clinical Endocrinology and Metabolism $842563-7$

Mizuno K, Tanaka T, Umesaki N and Ogita S (1999) Inhibition of cAMPmediated decidualization in human endometrial stromal cells by IL1 beta and laminin Hormone and Metabolic Research 31 307-310

Munn DH, Zhou M, Attwod JT, Bondarev I, Conway SJ, Marshall B, Brown C and Mellor AL (1998) Prevention of allogeneic fetal rejection by tryptophan catabolism Science 281 1191-1193

Murata T, Ushikubi F, Matsuoka T et al. (1997) Altered pain perception and inflammatory response in mice lacking prostacyclin receptor Nature 388 678-682

Nakano H, Shindo M, Sakon S, Nishinaka S, Mihara M, Yagita H and Okumura K (1998) Differential regulation of IkappaB kinase alpha and beta by two upstream kinases NF-kappaB-inducing kinase and mitogen-activated protein kinase/ERK kinase kinase-1 Proceedings National Academy of Sciences USA 95 3537-3542

Nasu K, Matsui N, Narahara H, Tanaka Y and Miyakawa I (1998) Effects of interferon-gamma on cytokine production by endometrial stromal cells Human Reproduction 13 2598-2601

Nemoto S, DiDonato JA and Lin A (1998) Coordinate regulation of IkappaB kinases by mitogen-activated protein kinase kinase kinase 1 and NF-kappaB-inducing kinase Molecular Cell Biology 18 7336-7343

Newberry RD, Stenson WF and Lorenz RG (1999) Cyclooxygenase-2dependent arachidonic acid metabolites are essential modulators of the intestinal immune response to dietary antigen Nature Medicine 5 900-906

Oliver C, Montes MJ, Galindo JA, Ruiz C and Olivares EG (1999) Human decidual stromal cells express alpha-smooth muscle actin and show ultrastructural similarities with myofibroblasts Human Reproduction 14 1599-1605

Ormandy CJ, Camus A, Barra J, Damotte D, Lucas B, Buteau H, Edery M, Brousse N, Babinet C, Binart N and Kelly PA (1997) Null mutation of the prolactin receptor gene produces multiple reproductive defects in the mouse Genes and Development 11 167-178

Paria BC, Tan J, Lubahn DB, Dey SK and Das SK (1999) Uterine decidual response occurs in estrogen receptor-alpha-deficient mice Endocrinology $1402704-2710$

Perrot-Aplanat $M$, Deng $M$, Fernandez H, Lelaidier C, Meduri G and Bouchard P (1994) Immunohistochemical localization of estradiol and progesterone receptors in human uterus throughout pregnancy: expression in endometrial blood vessels Journal of Clinical Endocrinology and Metabolism 78 216-224

Phipps RP, Stein SH and Roper RL (1991) A new view of prostaglandin E regulation of the immune response Immunology Today 12 349-352

Pickles VR (1967) Prostaglandins in the human endometrium International Journal of Fertility 12 335-338

Psychoyos A, Nikas G and Gravanis A (1995) The role of prostaglandins in blastocyst implantation Human Reproduction 10 30-42

Quayle AJ, Porter EM, Nussbaum AA, Wang YM, Brabec C, Yip KP and Mok SC (1998) Gene expression immunolocalization and secretion of human defensin-5 in human female reproductive tract American Journal of Pathology 152 1247-1258

Rampart M, Van Damme J, Zonnekyn L and Herman AG (1989) Granulocyte chemotactic protein/interleukin-8 induces plasma leakage and neutrophil accumulation in rabbit skin American Journal of Pathology 135 21-25

Rasweiler JJ, IV (1991) Spontaneous decidual reactions and menstruation in the black mastiff bat Molossus ater. American Journal of Anatomy $1911-22$

Robb L, Li R, Hartley L, Nandurkar HH, Koentgen F and Brgley CG (1998)
Infertility in female mice lacking the receptor for interleukin 11 is due to a defective uterine response to implantation Nature Medicine 4 303-308

Roper RL, Conrad DH, Brown DM, Warner GL and Phipps RP (1990) Prostaglandin $\mathrm{E}_{2}$ promotes IL-4-induced IgE and IgG-1 synthesis Journal of Immunology 145 2644-2651

Rothe M, Sarma V. Dixit VM and Goeddel DV (1995) TRAF2-mediated activation of NF-kappa B by TNF receptor 2 and CD40 Science 269 1424-1427

Royds JA, Dower SK, Qwarnstrom EE and Lewis CE (1998) Response of tumour cells to hypoxia: role of p53 and NFkB Molecular Pathology 51 55-61

Salamonsen LA and Woolley DE (1999) Menstruation: induction by matrix metalloproteinases and inflammatory cells Journal of Reproductive Immunology 44 1-27

Salamonsen LA, Marsh MM and Findlay JK (1999) Endometrial endothelin: regulator of uterine bleeding and endometrial repair Clinical and Experimental Pharmacology and Physiology 26 154-157

Sandberg T, Eriksson P, Gustavsson B and Casslen B (1997) Differential regulation of the plasminogen activator inhibitor-1 (PAI-1) gene expression by growth factors and progesterone in human endometrial stromal cells Molecular Human Reproduction 3 781-787

Sandberg T, Casslen B, Gustavsson B and Benraad TJ (1998) Human endothelial cell migration is stimulated by urokinase plasminogen activator:plasminogen activator inhibitor 1 complex released from endometrial stromal cells stimulated with transforming growth factor beta1; possible mechanism for paracrine stimulation of endometrial angiogenesis Biology of Reproduction 59 759-767

Sawai K, Matsuzaki N, Kameda T, Hashimoto K, Okada T, Shimoya K, Nobunaga T, Taga T, Kishimoto T and Saji F (1995) Leukemia inhibitory factor produced at the fetomaternal interface stimulates chorionic gonadotropin production: its possible implication during pregnancy including implantation period Journal of Clinical Endocrinology and Metabolism 80 1449-1456

Seitz M, Loetscher P, Dewald B, Towbin H, Ceska M and Baggiolini M (1994) Production of interleukin-1 receptor antagonist inflammatory chemotactic proteins and prostaglandin E by rheumatoid and osteoarthritic synoviocytes - regulation by IFN-gamma and IL-4 Journal of Immunology 152 2060-2065

Sempowski GD, Rozenblit J, Smith TJ and Phipps RP (1998) Human orbital fibroblasts are activated through CD40 to induce proinflammatory cytokine production American Journal of Physiology-Cell Physiology 43 C707-C714

Shankavaram UT, DeWitt DL, Funk SE, Sage EH and Wahl LM (1997) Regulation of human monocyte matrix metalloproteinases by SPARC Journal of Cell Physiology 173 327-334

Sharkey AM, King A, Clark DE, Burrows TD, Jokhi PP, Charnock-Jones DS, Loke YW and Smith SK (1999) Localization of leukemia inhibitory factor and its receptor in human placenta throughout pregnancy Biology of Reproduction 60 355-364

Sharkey AM, Day K, McPherson A, Malik S, Licence D, Smith SK and Charnock-Jones DS (2000) Vascular endothelial growth factor expression in human endometrium is regulated by hypoxia Journal of Clinical Endocrinology and Metabolism 85 402-409

Shiff SJ and Rigas B (1999) The role of cyclooxygenase inhibition in the antineoplastic effects of nonsteroidal antiinflammatory drugs (NSAIDs) Journal of Experimental Medicine, $190445-450$

Shimada T, Kawai T, Takeda K, Matsumoto M, Inoue J, Tatsumi Y, Kanamaru A and Akira S (1999) IKK-i a novel lipopolysaccharideinducible kinase that is related to IkappaB kinases International Immunolology 11 1357-1362

Simon C, Valbuena D, Krussel J, Bernal A, Murphy CR, Shaw T, Pellicer A and Polan ML (1998) Interleukin-1 receptor antagonist prevents embryonic implantation by a direct effect on the endometrial epithelium Fertility and Sterility 70 896-906

Singer CF, Marbaix E, Kokorine I, Lemoine P, Donnez J, Eeckhout $Y$ and Courtoy PJ (1997) Paracrine stimulation of interstitial collagenase (MMP-1) in the human endometrium by interleukin 1 alpha and its dual block by ovarian steroids Proceedings National Academy of Sciences USA $9410341-10345$ 
Singer CF, Marbaix E, Lemoine P, Courtoy PJ and Eeckhout Y (1999) Local cytokines induce differential expression of matrix metalloproteinases but not their tissue inhibitors in human endometrial fibroblasts European Journal of Biochemistry 259 40-45

Smith SK (1998) Angiogenesis vascular endothelial growth factor and the endometrium Human Reproduction Update 4 509-519

Smith SK, Abel MH, Kelly RW and Baird DT (1982) The synthesis of prostaglandins from persistent proliferative endometrium Journal of Clinical Endocrinology and Metabolism 55 284-289

Spaziani EP, Tsibris JC, Hunt LT, Benoit RR and O'Brien WF (1997) The effect of interleukin-1 beta and interleukin-4 on the expression of prostaglandin receptors EP1 and EP3 in amnion WISH cells American Journal of Reproductive Immunology 38 279-285

Spencer AG, Woods JW, Arakawa T, Singer II and Smith WL (1998) Subcellular localization of prostaglandin endoperoxide $\mathrm{H}$ synthases-1 and -2 by immunoelectron microscopy Journal of Biological Chemistry 273 9886-9893

Stewart CL (1994) The role of leukemia inhibitory factor (LIF) and other cytokines in regulating implantation in mammals Annals New York Academy of Sciences 734 157-165

Stewart CL, Kaspar P, Brunet LJ, Bhatt H, Gadi I, Kontgen F and Abbondanzo SJ (1992) Blastocyst implantation depends on maternal expression of leukaemia inhibitory factor Nature 359 76-79

Stirrat GM (1999) Choice of treatment for menorrhagia Lancet 353 2175-2176

Strassmann G, Patil Koota V, Finkelman F, Fong M and Kambayashi T (1994) Evidence for the involvement of interleukin 10 in the differential deactivation of murine peritoneal macrophages by prostaglandin $E_{2}$ Journal of Experimental Medicine 180 2365-2370

Tabibzadeh S (1994) Regulatory roles of IFN-gamma in human endometrium Annals New York Academy of Sciences 734 1-6

Tabibzadeh S (1995) Cytokines and endometrial microenvironments Seminars in Reproductive Endocrinology 13 133-141

Tabibzadeh S, Lessey B and Satyaswaroop PG (1998) Temporal and site-specific expression of transforming growth factor-beta4 in human endometrium Molecular Human Reproduction 4 595-602

Takeda K, Takeuchi O, Tsujimura T, Itami S, Adachi O, Kawai T, Sanjo H, Yoshikawa K, Terada N, Akira S (1999) Limb and skin abnormalities in mice lacking IKKalpha Science 284 313-316

Takeuchi M, Rothe $\mathbf{M}$ and Goeddel DV (1996) Anatomy of TRAF2. Distinct domains for nuclear factor-kappaB activation and association with tumor necrosis factor signaling proteins Journal of Biological Chemistry 271 19 935-19 942

Tanaka T, Umesaki N, Mizuno K, Chang L, Ohtaki S and Ogita S (1998) Enhancement of apoptotic susceptibility by interleukin-1 beta in human endometrial epithelial cells Gynecological Endocrinology 12 315-319

Tang B, Guller S and Gurpide E (1994) Mechanism of human endometrial stromal cells decidualization Annals New York Academy of Sciences $19-25$

Tang YQ, Yuan J, Osapay G, Osapay K, Tran D, Miller CJ, Ouellette AJ and Selsted ME (1999) A cyclic antimicrobial peptide produced in primate leukocytes by the ligation of two truncated alpha-defensins Science 286 498-502

Tauber PF, Cramer GM and Zaneveld LJ (1993) Effect of the intrauterine contraceptive device on protein components of human uterine fluid Contraception 48 494-512

Telfer JF, Lyall F, Norman JE and Cameron IT (1995) Identification of nitric oxide synthase in human uterus Human Reproduction 10, 19-23

Telgmann R and Gellersen B (1998) Marker genes of decidualization: activation of the decidual prolactin gene Human Reproduction Update 4 472-479

Tomee JFC, Hiemstra PS, Heinzel-Wieland R and Kauffman HF (1997) Antileukoprotease: and endogenous protein in the innate defense against fungi Journal of Infectious Diseases 176 740-747

Tseng JF, Ryan IP, Milam TD, Murai JT, Schriock ED, Landers DV and Taylor RN (1996) Interleukin-6 secretion in vitro is up-regulated ectopic and eutopic endometrial stromal cells from women with endometriosis Journal of Clinical Endocrinology and Metabolism $\mathbf{8 1}$ 1118-1122

Valore EV, Park CH, Quayle AJ, Wiles KR, McCray PB and Ganz T (1998) Human beta-defensin-1: an antimicrobial peptide of urogenital tissues Journal of Clinical Investigation 101 1633-1642

Vandermolen DT and Gu Y (1996) Human endometrial interleukin-6 (IL-6): in vivo messenger ribonucleic acid expression in vitro protein production and stimulation thereof by IL-1 beta Fertility and Sterility $66741-747$

Vigano P, Gaffuri B, Somigliana E, Busacca M, DiBlasio AM and Vignali M (1998) Expression of intercellular adhesion molecule (ICAM)1 mRNA and protein is enhanced in endometriosis versus endometrial stromal cells in culture Molecular Human Reproduction 4 1150-1156

Vogiagis D and Salamonsen LA (1999) Review: the role of leukaemia inhibitory factor in the establishment of pregnancy Journal of Endocrinology $160181-90$

Ware CB, Horowitz MC, Renshaw BR et al. (1995) Targeted disruption of the low-affinity leukemia inhibitory factor receptor gene causes placental skeletal neural and metabolic defects and results in perinatal death Development 121 1283-1299

Wegmann TG (1990) The cytokine basis for cross-talk between the maternal immune and reproductive systems Current Opinion in Immunology $2765-769$

Wiedow O, Harder J, Bartels J, Streit V and Christophers E (1998) Antileukoprotease in human skin: an antibiotic peptide constitutively produced by keratinocytes Biochemical and Biophysical Research Communications 248 904-909

Williams TJ and Morley J (1973) Prostaglandins as potentiators of increased vascular permeability in inflammation Nature 246 215-217

Wissink S, vanHeerde EC, vanderBurg B and vanderSaag PT (1998) A dual mechanism mediates repression of NF-kappa B activity by glucocorticoids Molecular Endocrinology 12 355-363

Xu J, Qiu Y, DeMayo FJ, Tsai SY, Tsai MJ and O'Malley BW (1998) Partial hormone resistance in mice with disruption of the steroid receptor coactivator-1 (SRC-1) gene Science 279, 1922-1925

Yang D, Chertov O, Bykovskaia SN, Chen Q, Buffo MJ, Shogan J, Anderson M, Schroder JM, Wang JM Howard OM and Oppenheim JJ (1999) Beta-defensins: linking innate and adaptive immunity through dendritic and T cell CCR6 Science 286 525-528

Yeaman GR, Guyre PM, Fanger MW, Collins JE, White HD, Rathbun W, Orndorff KA Gonzalez J, Stern JE and Wira CR (1997) Unique CD8(+) $\mathrm{T}$ cell-rich lymphoid aggregates in human uterine endometrium Journal of Leukocyte Biology 61 427-435

Yeaman GR, Collins JE, Currie JK, Guyre PM, Wira CR and Fanger MW (1998) IFN- $\gamma$ is produced by polymorphonuclear neutrophils in human uterine endometrium and by cultured peripheral blood polymorphonuclear neutrophils Journal of Immunology $\mathbf{1 6 0} 5145-5153$

Zeng L, An S and Goetzl EJ (1996) Regulation of expression of matrix metalloproteinase- 9 in early human T cells of the HSB 2 cultured line by the EP3 subtype of prostaglandin $\mathrm{E}_{2}$ receptor Journal of Biological Chemistry 27127 744-27 750

Zhang J, Lathbury LJ and Salamonsen LA (2000) Expression of the chemokine eotaxin and its receptor CCR3 in human endometrium Biology of Reproduction 62 404-411

Zhang XP, Morham SG, Langenbach R and Young DA (1999) Malignant transformation and antineoplastic actions of nonsteroidal antiinflammatory drugs (NSAIDs) on cyclooxygenase-null embryo fibroblasts Journal of Experimental Medicine 190 451-459

Zhang Y Cao H J Graf B Meekins H Smith T J and Phipps RP (1998) CD40 engagement up-regulates cyclooxygenase-2 expression and prostaglandin $E_{2}$ production in human lung fibroblasts Journal of Immunology 160 1053-1057

Zheng H, Fletcher D, Kozak W et al. (1995) Resistance to fever induction and impaired acute-phase response in interleukin-1-beta-deficient mice Immunity 3 9-19 